\title{
Plasma Neurofilament Light for Prediction of Disease Progression in Familial Frontotemporal Lobar Degeneration
}

Julio C. Rojas, MD, PhD, Ping Wang, MS, Adam M. Staffaroni, PhD, Carolin Heller, BSc, Yann Cobigo, PhD, Amy Wolf, BS, Sheng-Yang M. Goh, BS, Peter A. Ljubenkov, MD, Hilary W. Heuer, PhD, Jamie C. Fong, MS, Joanne B. Taylor, MS, Eliseo Veras, BS, Linan Song, Andreas Jeromin, PhD, David Hanlon, PhD, Lili Yu, Arvind Khinikar, Rajeev Sivasankaran, PhD, Agnieszka Kieloch, Marie-Anne Valentin, Anna M. Karydas, Laura L. Mitic, PhD, Rodney Pearlman, John Kornak, PhD, Joel H. Kramer, PsyD, Bruce L. Miller, MD, Kejal Kantarci, MD, David S. Knopman, MD, Neill Graff-Radford, MD, Leonard Petrucelli, PhD, Rosa Rademakers, PhD, David J. Irwin, MD, Murray Grossman, MD, EdD, Eliana Marisa Ramos, PhD, Giovanni Coppola, MD, Mario F. Mendez, MD, PhD, Yvette Bordelon, MD, PhD, Bradford C. Dickerson, MD, Nupur Ghoshal, MD, PhD, Edward D. Huey, MD, Ian R. Mackenzie, MD, Brian S. Appleby, MD,

Kimiko Domoto-Reilly, MD, Ging-Yuek R. Hsiung, MD, Arthur W. Toga, PhD, Sandra Weintraub, PhD, Daniel I. Kaufer, MD, Diana Kerwin, MD, Irene Litvan, MD, Chiadikaobi U. Onyike, MD, Alexander Pantelyat, MD, Erik D. Roberson, MD, PhD, Maria C. Tartaglia, MD, Tatiana Foroud, PhD, Weiping Chen, MS, Julie Czerkowicz, MS, Danielle L. Graham, PhD, John C. van Swieten, PhD, Barbara Borroni, MD, Raquel Sanchez-Valle, PhD, Fermin Moreno, MD, PhD, Robert Laforce, MD, PhD, Caroline Graff, MD, PhD, Matthis Synofzik, MD, Daniela Galimberti, PhD, James B. Rowe, MD, PhD, Mario Masellis, MD, PhD, Elizabeth Finger, MD, Rik Vandenberghe, MD, PhD,

Alexandre de Mendonça, MD, PhD, Fabrizio Tagliavini, MD, Isabel Santana, MD, PhD, Simon Ducharme, MD, Chris R. Butler, PhD, FRCP, Alexander Gerhard, MD, MRCP, Johannes Levin, MD, Adrian Danek, MD, Markus Otto, MD, Sandro Sorbi, MD, David M. Cash, PhD, Rhian S. Convery, MSc, Martina Bocchetta, PhD, Martha Foiani, MRes, Caroline V. Greaves, BSc, Georgia Peakman, MSc, Lucy Russell, PhD, Imogen Swift, MSc, Emily Todd, MRes, Jonathan D. Rohrer, PhD, FRCP, Bradley F. Boeve, MD, Howard J. Rosen, MD, and Adam L. Boxer, MD, PhD, on behalf of the ALLFTD and GENFI consortia

Neurology ${ }^{\circledR}$ 2021;96:e2296-e2312. doi:10.1212/WNL.0000000000011848

\section{Abstract}

\section{Objective}

We tested the hypothesis that plasma neurofilament light chain (NfL) identifies asymptomatic carriers of familial frontotemporal lobar degeneration (FTLD)-causing mutations at risk of disease progression.

\author{
Correspondence \\ Dr. Rojas \\ jrojasmartinez@ \\ memory.ucsf.edu
}

\author{
MORE ONLINE \\ $\rightarrow$ Class of Evidence \\ Criteria for rating \\ therapeutic and diagnostic \\ studies \\ NPub.org/coe
}

\begin{abstract}
From the University of California, San Francisco (J.C.R., P.W., A.M.S., Y.C., A.W., S.-Y.M.G., P.A.L., H.W.H., J.C.F., J.B.T., A.M.K., L.L.M., J.K., J.H.K., B.L.M., H.J.S., A.L.B.); UK Dementia Research Centre (C.H., D.M.C., R.S.C., M.B., M.F., C.V.G., G.P., L.R., I.S., E.T., J.D.R.), UCL Institute of Neurology, Queen Square, London; Quanterix Corp (E.V., L.S., A.J., D.H.), Lexington; Novartis Institutes for Biomedical Research Inc (L.Y., A. Khinikar, R.S.), Cambridge, MA; Novartis Pharma AG (A. Kieloch, M.-A.V.), Basel, Switzerland; Bluefield Project to Cure Frontotemporal Dementia (L.L.M., R.P.), San Francisco, CA; Mayo Clinic (K.K., D.S.K., B.F.B.), Rochester, MN; Mayo Clinic (N.G.-R., L.P., R.R.), Jacksonville, FL; University of Pennsylvania (D.J.I., M.G.), Philadelphia; University of California, Los Angeles (E.M.R., G.C., M.F.M., Y.B.); Harvard University/Massachusetts General Hospital (B.D.C.), Boston, MA; Washington University (N.G.), St. Louis, MO; Columbia University (E.D.H.), New York, NY; University of British Columbia (I.R.M., G.-Y.R.H.), Vancouver, Canada; Case Western Reserve University (B.S.A.), Cleveland, $\mathrm{OH}$; University of Washington (K.D.-R.), Seattle; Laboratory of Neuroimaging (A.W.T.), University of Southern California, Los Angeles; Northwestern University (S.W.), Chicago, IL; University of North Carolina (D.I.K.), Chapel Hill; Texas Health Presbyterian Hospital Dallas (D.K.); University of California, San Diego (I.L.); Johns Hopkins Hospital (C.U.O., A.P.), Baltimore, MD; University of Alabama at Birmingham (E.D.R.); University of Toronto (M.C.T., M.M.), Ontario, Canada; Indiana University School of Medicine (T.F.), Indianapolis; Biogen Inc (W.C., J.C., D.L.G.), Cambridge, MA; Erasmus Medical Centre (J.C.v.S.), Rotterdam, the Netherlands; University of Brescia (B.B.), Italy; University of Barcelona (R.S.-V.); Donostia University Hospital (F.M.), San Sebastian, Gipuzkoa, Spain; Clinique Interdisciplinaire de Mémoire (R.L.), Département des Sciences Neurologiques, CHU de Québec; Faculté de Médecine (R.L.), Université Laval, Quebec, Canada; Center for Alzheimer Research (C.G.), Division of Neurogeriatrics, Department of Neurobiology, Care Sciences and Society, Bioclinicum, Karolinska Institutet; Unit for Hereditary Dementias (C.G.), Theme Aging, Karolinska University Hospital, Solna, Sweden; University of Tübingen (M.S.); Center for Neurodegenerative Diseases (DZNE) (M.S.), Tübingen, Germany; Fondazione IRCCS Ospedale Policlinico (D.G.); University of Milan (D.G.), Centro Dino Ferrari, Italy; Department of Clinical Neurosciences and Cambridge University Hospital (J.B.R.), University of Cambridge, UK; University of Western Ontario (E.F.), London, Canada; KU Leuven (R.V.), Belgium; Neurology Service (R.V.), University Hospitals Leuven, Belgium; University of Lisbon (A.d.M.), Portugal; Fondazione IRCCS Istituto Neurologico Carlo Besta (F.T.), Milan, Italy; University of Coimbra (I.S.), Portugal; McGill University (S.D.), Montreal, Québec, Canada; University of Oxford (C.R.B.); Wolfson Molecular Imaging Centre (A.G.), University of Manchester, UK; University of Duisburg-Essen (A.G.), Duisberg; Ludwig-Maximilians-Universität München (J.L., A.D.); German Center for Neurodegenerative Diseases (J.L.), Munich Cluster for Systems Neurology (SyNergy); University of UIm (M.O.), Germany; and Department of Neuroscience, Psychology, Drug Research and Child Health (S.S.), University of Florence, and IRCCS Fondazione Don Carlo Gnocchi, Florence, Italy.
\end{abstract}

Go to Neurology.org/N for full disclosures. Funding information and disclosures deemed relevant by the authors, if any, are provided at the end of the article.

Coinvestigators are listed in the Appendixes 2 and 3 at links.Iww.com/WNL/B350 and links.Iww.com/WNL/B351.

The Article Processing Charge was funded by the NIH.

This is an open access article distributed under the terms of the Creative Commons Attribution License 4.0 (CC BY), which permits unrestricted use, distribution, and reproduction in any medium, provided the original work is properly cited. 


\section{Glossary}

ALLFTD $=$ ARTFL LEFFTDS Longitudinal Frontotemporal Dementia; ARTFL $=$ Advancing Research and Treatment in Frontotemporal Lobar Degeneration; AUC = area under the curve; bvFTD = behavioral variant frontotemporal dementia; CBS = corticobasal syndrome; CDR+NACC-FTLD = CDR Dementia Staging Instrument plus Behavior and Language domains from the National Alzheimer's Disease Coordinating Center Frontotemporal Lobar Degeneration module; CGI-S = Clinical Global Impression of Severity; C90rf72 = chromosome 9 open reading frame 72; CI = confidence interval; FAS = Functional Assessment Scale; FTLD = frontotemporal lobar degeneration; f-FTLD = familial FTLD; FTD $/$ ALS = frontotemporal dementia with amyotrophic lateral sclerosis; GENFI = Genetic Frontotemporal Dementia Initiative; GRN = progranulin; LEFFTDS = Longitudinal Evaluation of Familial Frontotemporal Dementia Subjects; MAPT = microtubuleassociated protein tau; MBI/MCI = mild behavioral or cognitive impairment; MMSE = Mini-Mental State Examination; MoCA = Montreal Cognitive Assessment; NfL = neurofilament light chain; $\mathbf{p}-\mathbf{N f H}=$ phosphorylated neurofilament heavy chain; PPA = primary progressive aphasia; $\mathbf{p}$-tau $=$ phosphorylated tau $181 ; \mathbf{R O C}=$ receiver operating characteristic; $\mathbf{s b}=\mathbf{s u m}$ of boxes; SEADL = Schwab and England Activities of Daily Living; Simoa = single-molecule array.

\section{Methods}

Baseline plasma NfL concentrations were measured with single-molecule array in original $(\mathrm{n}=277)$ and validation $(\mathrm{n}=297)$ cohorts. C9orf72, GRN, and MAPT mutation carriers and noncarriers from the same families were classified by disease severity (asymptomatic, prodromal, and full phenotype) using the CDR Dementia Staging Instrument plus behavior and language domains from the National Alzheimer's Disease Coordinating Center FTLD module (CDR+NACC-FTLD). Linear mixedeffect models related NfL to clinical variables.

\section{Results}

In both cohorts, baseline NfL was higher in asymptomatic mutation carriers who showed phenoconversion or disease progression compared to nonprogressors (original: $11.4 \pm 7 \mathrm{pg} / \mathrm{mL}$ vs $6.7 \pm 5 \mathrm{pg} / \mathrm{mL}, p=0.002$; validation: $14.1 \pm 12 \mathrm{pg} / \mathrm{mL}$ vs 8.7 $\pm 6 \mathrm{pg} / \mathrm{mL}, p=0.035$ ). Plasma NfL discriminated symptomatic from asymptomatic mutation carriers or those with prodromal disease (original cutoff: $13.6 \mathrm{pg} / \mathrm{mL}, 87.5 \%$ sensitivity, $82.7 \%$ specificity; validation cutoff: $19.8 \mathrm{pg} / \mathrm{mL}, 87.4 \%$ sensitivity, $84.3 \%$ specificity). Higher baseline NfL correlated with worse longitudinal CDR+NACC-FTLD sum of boxes scores, neuropsychological function, and atrophy, regardless of genotype or disease severity, including asymptomatic mutation carriers.

\section{Conclusions}

Plasma NfL identifies asymptomatic carriers of FTLD-causing mutations at short-term risk of disease progression and is a potential tool to select participants for prevention clinical trials.

\section{Trial Registration Information}

ClinicalTrials.gov Identifier: NCT02372773 and NCT02365922.

\section{Classification of Evidence}

This study provides Class I evidence that in carriers of FTLD-causing mutations, elevation of plasma NfL predicts short-term risk of clinical progression.

Blood-based biomarkers are uniquely valuable for therapeutic development because they are easily obtainable and relatively inexpensive. ${ }^{1}$ Frontotemporal lobar degeneration (FTLD) produces behavioral, cognitive, language, and motor deficits that impair the quality of life of patients and caregivers more severely than other forms of dementia. ${ }^{2}$ About $20 \%$ to $30 \%$ of FTLD cases are familial, and $\approx 60 \%$ of those are caused by autosomal dominant mutations in 3 genes $^{3}$ : chromosome 9 open reading frame $72(C 9$ orf 72$),{ }^{4}$ progranulin $(G R N),{ }^{5}$ and microtubule-associated protein tau $(M A P T){ }^{6}$ Several therapies are poised to begin clinical trials for familial FTLD (fFTLD) due to these mutations. ${ }^{7}$ Planning such studies is challenging due to the low f-FTLD prevalence and the lack of good clinical endpoints to monitor disease severity and therapeutic response.

Neurofilament light chain (NfL) is a sensitive marker of neurodegeneration. ${ }^{8}$ CSF NfL is elevated in patients with FTLD compared to patients with Alzheimer disease and healthy controls, ${ }^{9-12}$ with concentrations that correlate with disease severity, cognitive function, and disease progression. ${ }^{13,14} \mathrm{CSF}$ $\mathrm{NfL}$ concentrations normalize on effective treatment in multiple sclerosis ${ }^{15}$ and spinal muscle atrophy, ${ }^{16}$ suggesting that $\mathrm{NfL}$ is sensitive to treatment effects. Serum NfL is elevated in FTLD,${ }^{17}$ and in symptomatic carriers of f-FTLD-causing mutations, concentrations correlate with brain atrophy. ${ }^{18} \mathrm{We}$ 
tested the hypothesis that plasma NfL could identify asymptomatic f-FTLD mutation carriers at high risk of progression to symptomatic disease. We examined baseline plasma NfL differences related to phenotype, genotype, and disease severity and whether it predicts disease progression in 2 independent cohorts.

\section{Methods}

The primary research question was the following: do plasma NfL concentrations identify f-FTLD mutation carriers at risk of clinical progression (Class I level of evidence)?

\section{Standard Protocol Approvals, Registrations, and Patient Consents}

Participants or their caregivers provided written informed consent, and the study procedures were approved by the local Institutional Review Board committees at each of the participating centers. Patients were recruited through the North American multicenter observational studies Longitudinal Evaluation of Familial Frontotemporal Dementia Subjects (LEFFTDS; ClinicalTrials.gov NCT02372773) and Advancing Research and Treatment in Frontotemporal Lobar Degeneration (ARTFL; ClinicalTrials.gov NCT02365922) ${ }^{19}$ and the Genetic Frontotemporal Dementia Initiative (GENFI). ${ }^{20}$

\section{Participants}

Participants were divided into original (LEFFTDS/ARTFL, $\mathrm{n}$ $=277$ ) and validation (GENFI, $\mathrm{n}=297$ ) cohorts. LEFFTDS/ ARTFL is a North American network of 19 clinical research centers. LEFFTDS enrolled members of families with a known mutation in 1 of the 3 major FTLD genes: C9orf72, GRN, and MAPT. ARTFL enrolled participants who met research criteria for an FTLD syndrome and asymptomatic individuals with a family history of an FTLD syndrome, regardless of whether an FTLD-causing mutation had been identified in the family. ${ }^{19}$ On evaluation, some participants with a family history of FTLD were determined to have prodromal disease or mild cognitive or behavioral impairment (MBI/MCI), as defined previously. ${ }^{21}$ GENFI involves 25 research centers across Europe and Canada and enrolls symptomatic carriers of mutations in the 3 major FTLD genes with frontotemporal dementia and those at risk of carrying a mutation because a first-degree relative is a known symptomatic carrier. Both cohorts consisted of participants with available baseline $\mathrm{NfL}$ concentrations, known genotype, and CDR Dementia Staging Instrument plus behavior and language domains from the National Alzheimer's Disease Coordinating Center FTLD module (CDR+NACC-FTLD) global and sum of boxes (sb) scores. ${ }^{21}$ Mutation noncarriers with CDR+NACC-FTLD global score $>0$ were excluded ( 11 in the original cohort and 22 in the validation cohort). The validation cohort data have been reported previously. ${ }^{22}$ In the original cohort, clinically defined phenotypes included 184 normal (66.7\%), 12 mild behavioral impairment (4.3\%), 16 mild cognitive impairment (5.8\%), 3 amnestic dementia (1.1\%), 48 behavioral variant frontotemporal dementia
(bvFTD; 17.4\%), 7 frontotemporal dementia with amyotrophic lateral sclerosis (FTD/ALS; $2.5 \%), 4$ primary progressive aphasia (PPA; nonfluent or semantic, 1.4\%), and 3 corticobasal syndrome (CBS; $1.1 \%)$. Participants in the validation cohort included 240 normal (80.8\%), 36 bvFTD (12.1\%), 6 FTD/ALS (2\%), 3 CBS (1\%), and 12 PPA (4\%). Data on whether there was conversion from asymptomatic to $\mathrm{MBI} / \mathrm{MCI}$ or full phenotype or from MBI/MCI to full phenotype were available in 221 of 277 participants in the original cohort and in 159 of 297 participants in the validation cohort.

\section{Clinical Procedures}

Participants underwent annual standardized evaluations that included neurologic assessment, caregiver or companion interview, neuropsychological testing, brain MRI, and biofluid collection for up to 3 years in the original cohort and for 2 years in the validation cohort. Clinical scales included CDR+NACCFTLD global and CDR+NACC-FTLDsb ${ }^{21}$ and Clinical Global Impression of Severity (CGI-S), ${ }^{23}$ which are based on semistructured interviews and provide global measures of clinical severity; Montreal Cognitive Assessment (MoCA); Unified Parkinson's Disease Rating Scale III, Motor Section ${ }^{24}$; Schwab and England Activities of Daily Living (SEADL), for measurement of impairment in activities of daily living ${ }^{25}$; Functional Assessment Scale (FAS), for assessment of impairment in instrumental activities ${ }^{26}$; and Neuropsychiatric Inventory. ${ }^{27}$ CDR+NACC-FTLD and Mini-Mental State Examination (MMSE) were the only severity scales available in the validation cohort. Neuropsychological testing available in both cohorts included the California Verbal Learning Test-Short Form, immediate and delayed recall ${ }^{28}$; the Benson figure re$\mathrm{call}^{29}$; forward and backward digit span; number of correct trials; Trail-Making Test Parts A and B (time to completion) ${ }^{30}$; and phonemic and semantic fluency. In the original cohort, blood samples were centrifuged at $1,500 \mathrm{~g}$ at $4^{\circ} \mathrm{C}$ for 15 minutes. Plasma was aliquoted in $1,000-\mu \mathrm{l}$ vials and stored at $-80^{\circ} \mathrm{C}$ at the National Centralized Repository for Alzheimer's Disease and Related Dementias. In the validation cohort, blood samples were collected and processed as previously reported. ${ }^{22}$ Genetic screening was conducted to identify FTLD-causing mutations in the C9orf72, GRN, and MAPT genes and APOE polymorphisms as described previously. ${ }^{22,31}$

\section{Plasma NfL Measurement}

In the original cohort, plasma NfL concentrations were measured at baseline with single-molecule array technology (Simoa), using the commercially available NF-light digital immunoassay kit (Quanterix, Lexington, MA). Plasma samples were thawed at room temperature (1 cycle), mixed thoroughly, and centrifuged at $14,000 \mathrm{~g}$ for 3 minutes. The supernatant was loaded onto a Quanterix HD-1 Analyzer with a 1:4 specified dilution. Measures were completed in duplicate over a total of 6 batches, each with an 8-point calibration curve tested in triplicate and 2 controls tested in duplicate. Plasma concentrations were interpolated from the calibration curve within the same batch and corrected for the dilution. All samples were quantifiable within the dynamic range of 0.69 to $2,000 \mathrm{pg} / \mathrm{mL}$ and 
with an average coefficient of variation of $6.5 \%$. Measurements were completed using the same platform in 2 centers: Quanterix ( $\mathrm{n}=226$, February 2018) and Novartis Institutes for Biomedical Research $(n=64$, July 2018). Samples from a subset of 186 participants were analyzed twice, independently by each center, with plasma NfL concentrations that were highly correlated $(r=0.98, p<0.001)$. The samples analyzed by the 2 centers also had comparable means and SDs (Quanterix $21.8 \pm 35 \mathrm{pg} / \mathrm{mL}$ and Novartis $20.2 \pm 34 \mathrm{pg} / \mathrm{mL}$ ), and there were no differences in the median plasma NfL concentrations in 2 groups of age-matched asymptomatic noncarrier controls measured separately (Quanterix $6.9 \pm 4 \mathrm{pg} / \mathrm{mL}, \mathrm{n}=38$ vs Novartis $6.4 \pm 6 \mathrm{pg} / \mathrm{mL}, \mathrm{n}=50, p=0.6)$. The center where samples were analyzed was added as a covariate in statistical analyses. Instrument operators were blinded to clinical and genetic information. In the validation cohort, plasma $\mathrm{NfL}$ concentrations were measured with the multiplex Simoa Neurology 4-Plex A kit. ${ }^{22}$

\section{CSF Biomarker Measurements}

CSF biomarkers were available in 113 of the 277 participants at baseline in the original cohort only. Using fit-for-purpose immunoassays, CSF samples were analyzed for NfL, tau, phosphorylated tau ${ }_{181}$ ( $\mathrm{p}$-tau), neurogranin, and phosphorylated neurofilament heavy chain $(\mathrm{p}-\mathrm{NfH})$ at the following dilutions, $1: 50$, neat, $1: 20$, neat, and $1: 4$, respectively. NfL and tau were measured on the Quanterix Simoa HD-1 (catalog Nos. 103186 and 101552, respectively); p-tau was measured with the Innotest kit (catalog No. 81581); neurogranin was measured with the Euroimmun kit (item code EQ-65519601-L); and p-NfH was measured on the Protein Simple Ella platform (catalog No. SPCKB-PS-000519). Measurements were conducted by an independent laboratory with operators blinded to clinical data (Biogen, Inc, Cambridge, MA).

\section{Neuroimaging}

Brain MRI was obtained in the original cohort as described previously $^{32}$ within 45 days of plasma collection except for 15 patients for whom images were obtained within $>45$ days of plasma collection (median 60 days, range 50-423 days). To simplify relationships with plasma NfL and to control for multiple comparisons, bilateral frontal and temporal gray matter lobar composites were created with regions of interest involved in FTLD syndromes. Frontal regions included frontal pole, lateral orbitofrontal cortex, medial orbitofrontal cortex, middle frontal gyrus, pars opercularis, pars orbitalis, pars triangularis, superior frontal gyrus, and precentral gyrus. Anterior cingulate (caudal and rostral) and insula were also included in the frontal composite, given their significant involvement in FTLD. ${ }^{33}$ Temporal regions included banks of the superior temporal sulcus, entorhinal cortex, fusiform gyrus, middle temporal gyrus, parahippocampal cortex, superior temporal gyrus, temporal pole, and transverse temporal gyrus.

\section{Statistical Analyses}

Biofluid measurements, disease status determination, and statistical analyses were performed separately by different investigators. Original and validation cohort data were handled independently. Data were visually explored with boxplots. NfL data were not normally distributed. Group differences in NfL concentrations were determined with nonparametric tests. Log-transformed NfL data were used as outcome in general linear models to determine between-group differences in $\mathrm{NfL}$ concentrations corrected for age and sex. Receiver operating characteristic (ROC) curves tested the diagnostic accuracy of plasma NfL concentrations. Combined forward and backward stepwise linear regressions controlling for age, sex, and genotype determined baseline associations between plasma NfL and clinical variables. Starting with minimal models, the stepwise criteria were such that a variable entered a model when $p<0.05$, and it was removed when $p \geq 0.1$. For associations with gray matter volumes, total intracranial volume was an additional control variable. ${ }^{32}$ Linear mixed models tested the ability of baseline log plasma NfL to predict change in clinical variables. All models included interaction terms of log plasma NfL with time as a discrete predictor. Models used compound symmetry covariance and random slopes and intercepts and were controlled for by sex, age, genotype, clinical center, and, when modeling prediction of gray matter volumes, total intracranial volume. Models were run with log plasma NfL as a continuous independent variable and subsequently as a categorical independent variable based on cutoff points derived from Youden indices estimated with ROC curves. Models were run separately for each of the disease severity levels defined by the CDR+NACC-FTLD global score: normal or asymptomatic (carriers and noncarriers run independently) (0), MBI/MCI or prodromal disease $(0.5)$, and dementia or full phenotype $(\geq 1) .{ }^{21}$ Model results were corrected for multiple comparisons across dependent variables for a given disease severity level using false discovery rate. ${ }^{34}$ Analyses were done with SPSS Statistics software, version 26 (IBM, Armonk, NY) and GraphPad Prism, version 8.4 (GraphPad, La Jolla, CA).

\section{Data Availability}

Joint ARTFL and LEFFTDS data and biospecimens and GENFI data are available to qualified investigators for replication of the present study results or further projects.

\section{Results}

\section{Group Differences in Baseline Plasma NfL Concentrations, Original Cohort}

Of 277 individuals with baseline evaluations (table 1), 221 (79.7\%) and 148 (53.4\%) also had follow-up data available for years 1 and 2, respectively. In all genotypes combined and after correction for age and sex, amnestic dementia, bvFTD, FTD/ ALS, CBS, and PPA phenotypes had higher plasma NfL concentrations than asymptomatic participants (mutation carriers and noncarriers combined) and those with MCI (figure 1).

As defined by disease severity, $65.7 \%$ of the participants $(33.2 \%$ carriers and $32.5 \%$ noncarriers) were asymptomatic (CDR+NACC-FTLD score 0), 11.9\% had MBI/MCI (CDR+NACC- 
Table 1 Baseline Demographic Characteristics by Disease Severity, Original Cohort ${ }^{\text {ae }}$

\begin{tabular}{|c|c|c|c|c|}
\hline & $\begin{array}{l}\text { Asymptomatic } \\
\text { Noncarrier }(n=90)\end{array}$ & $\begin{array}{l}\text { Asymptomatic } \\
\text { Carrier }(n=92)\end{array}$ & $\begin{array}{l}\mathrm{MCl} / \mathrm{MBI} \\
(\mathrm{n}=33)\end{array}$ & $\begin{array}{l}\text { Full Phenotype } \\
(n=62)\end{array}$ \\
\hline $\begin{array}{l}\text { Age, median } \\
\text { (IQR, range), y }\end{array}$ & $50(19,24-76)$ & $44(21,19-71)$ & $54(13,29-80)^{b}$ & $61.5(18,33-74)^{b c}$ \\
\hline Sex: M/F, n & $32 / 58$ & $43 / 49$ & $18 / 15$ & $24 / 38$ \\
\hline Plasma NfL, pg/mL & $6.4(5)$ & $7.1(5)$ & $12.2(12)^{\mathrm{bc}}$ & $24.1(21)^{\mathrm{bcd}}$ \\
\hline \multicolumn{5}{|l|}{ Genotype } \\
\hline Noncarriers, n (\%) & $90(100)$ & $0(0)$ & $0(0)$ & $0(0)$ \\
\hline $\mathrm{NfL}, \mathrm{pg} / \mathrm{mL}$ & $6.7(5)$ & - & - & - \\
\hline C9orf72, n (\%) & $0(0)$ & $35(43.8)$ & $13(16.2)$ & $32(40)$ \\
\hline $\mathrm{NfL}, \mathrm{pg} / \mathrm{mL}$ & - & $6.6(5)$ & $13.6(34)^{b}$ & $33.9(33)^{b}$ \\
\hline GRN, $\mathrm{n}(\%)$ & $0(0)$ & 27 (52.9) & $11(21.6)$ & $13(25.5)$ \\
\hline $\mathrm{NfL}, \mathrm{pg} / \mathrm{mL}$ & - & $9.1(7)$ & $7.1(8)$ & $61.5(54)^{\mathrm{bd}}$ \\
\hline MAPT, n (\%) & $0(0)$ & $30(53.6)$ & $9(16.1)$ & $17(30.4)$ \\
\hline $\mathrm{NfL}, \mathrm{pg} / \mathrm{mL}$ & - & $7.8(5)$ & $12.1(11)$ & $20.5(11)^{\mathrm{bd}}$ \\
\hline CDR+NACC-FTLDsb score & $0(0)$ & $0(0)$ & $1.5(2)^{b c}$ & $7.2(5)^{\mathrm{bcd}}$ \\
\hline MoCA score & $28(3)$ & $28(3)$ & $25(4)^{b c}$ & $20.5(5)^{\mathrm{bcd}}$ \\
\hline UPDRS score & $0(0)$ & $0(0)$ & $0(4)^{b c}$ & $3(7)^{b c}$ \\
\hline CGI-S score & $1(0)$ & $1(0)$ & $2(1)^{b c}$ & $3(1)^{\mathrm{bcd}}$ \\
\hline SEADL score & $100(0)$ & $100(0)$ & $90(10)^{b c}$ & $65(25)^{b c d}$ \\
\hline FAS score & $0(0)$ & $0(0)$ & $0(2)$ & $11(17)^{\mathrm{bcd}}$ \\
\hline NPI score & $0(1)$ & $0(2)$ & $6(9)^{b c}$ & $6.5(9)^{\mathrm{bc}}$ \\
\hline CVLTi score & $9(3)$ & $8(2)$ & $7(3)$ & $3.5(6)^{b c d}$ \\
\hline CVLTd score & $8(3)$ & $7(3)$ & $6(6)$ & $4(6)^{b c d}$ \\
\hline $\begin{array}{l}\text { Benson delayed } \\
\text { recall score }\end{array}$ & $13(4)$ & $13(3)$ & $12(4)$ & $8.5(6)^{\mathrm{bcd}}$ \\
\hline Digits forward score & $7(2)$ & $7(2)$ & $6(2)$ & $5.5(2)^{b c d}$ \\
\hline Digits backward score & $6(1)$ & $5(1)$ & $5(2)$ & $4(1)^{\mathrm{bc}}$ \\
\hline $\begin{array}{l}\text { Trail-Making Test } \\
\text { Part A score, } \mathbf{s}\end{array}$ & $22(10)$ & $21(8)$ & $25(14)^{c}$ & $45(17)^{d}$ \\
\hline $\begin{array}{l}\text { Trail-Making Test } \\
\text { Part B score, s }\end{array}$ & $49(29)$ & $58(28)$ & $59(77)^{\mathrm{bc}}$ & $92.5(105)^{b c d}$ \\
\hline Phonemic fluency score & $15(7)$ & $15(7)$ & $13(8)^{b}$ & $6(8)^{b c d}$ \\
\hline Semantic fluency score & $23(8)$ & $23(8)$ & $21(8)$ & $13(6)^{\mathrm{bcd}}$ \\
\hline $\mathrm{TIV}^{\mathrm{f}} \mathrm{mm}^{3} \times 10^{6}$ & $1.4(0.1)$ & $1.4(0.2)$ & $1.4(0.1)$ & $1.3(0.2)$ \\
\hline Left frontal, ${ }^{\mathrm{f}} \mathrm{mm}^{3} \times 10^{4}$ & $4.7(0.5)$ & $4.6(0.7)$ & $4.3(0.9)^{c}$ & $3.7(1.2)^{\mathrm{bcd}}$ \\
\hline Right frontal, ${ }^{\mathrm{f}} \mathrm{mm}^{3} \times 10^{4}$ & $4.7(0.6)$ & $4.6(0.7)$ & $4.2(1.0)^{c}$ & $3.7(1.2)^{\mathrm{bcd}}$ \\
\hline Left temporal, ${ }^{\mathrm{f}} \mathrm{mm}^{3} \times 10^{4}$ & $2.7(0.3)$ & $2.7(0.3)$ & $2.7(0.8)$ & $2.1(0.6)^{\mathrm{bcd}}$ \\
\hline Right temporal, ${ }^{\mathrm{f}} \mathrm{mm}^{3} \times 10^{4}$ & $2.6(03)$ & $2.6(0.3)$ & $2.6(0.7)^{c}$ & $2.1(0.6)^{\mathrm{bcd}}$ \\
\hline CSF NfL, pg/mL & $313(359)$ & $331.5(375)$ & $615.5(834)$ & $1,659.7(2099)^{\mathrm{bc}}$ \\
\hline CSF tau, pg/mL & $121.2(87)$ & $146.3(102)$ & $136.8(91)$ & $206.3(153)^{c}$ \\
\hline CSF p-tau, pg/mL & $37.4(20)$ & $39.9(16)$ & $34.5(12)$ & $31.9(23)$ \\
\hline
\end{tabular}


Table 1 Baseline Demographic Characteristics by Disease Severity, Original Cohort ${ }^{\text {ae }}$ (continued)

\begin{tabular}{lllll}
\hline & $\begin{array}{l}\text { Asymptomatic } \\
\text { Noncarrier }(\mathbf{n}=\mathbf{9 0})\end{array}$ & $\begin{array}{l}\text { Asymptomatic } \\
\text { Carrier }(\mathbf{n = 9 2})\end{array}$ & $\begin{array}{l}\text { MCI/MBI } \\
(\mathbf{n}=\mathbf{3 3})\end{array}$ & $\begin{array}{l}\text { Full Phenotype } \\
(\mathbf{n = 6 2})\end{array}$ \\
\hline CSF neurogranin, pg/mL & $312.8(156)$ & $364.7(184)$ & $311.7(252)$ & $278.6(148)$ \\
\hline CSF p-NfH, pg/mL & $662.9(392)$ & $485.9(571)$ & $768.3(585)$ & $1,252.1(1,368)^{\mathrm{bc}}$ \\
\hline
\end{tabular}

Abbreviations: CDR+NACC-FTLDsb $=$ CDR Dementia Staging Instrument plus Behavior and Language domains from the National Alzheimer's Disease Coordinating Center Frontotemporal Lobar Degeneration module sum of boxes score; CGI-S = Clinical Global Impression of Severity; CVLTd = California Verbal Learning Test; Short Form-delayed recall (number of words); CVLTi = California Verbal Learning Test; Short Form-immediate recall (number of words); FAS = Functional Assessment Scale; $\mathrm{MBI} / \mathrm{MCl}=$ mild behavioral impairment $/$ mild cognitive impairment; $\mathrm{MoCA}=$ Montreal Cognitive Assessment; $\mathrm{NfL}=$ plasma neurofilament-light chain (uncorrected); NPI = Neuropsychiatric Inventory; p-NfH = phosphorylated neurofilament heavy chain; $\mathrm{p}$-tau = phosphorylated $\operatorname{tau}_{181} ;$ SEADL = Schwab and England Activities of Daily Living score; TIV = total intracranial volume; UPDRS = Unified Parkinson's Disease Rating Scale, motor section.

a Disease severity determined by CDR+NACC-FTLD score $0=$ asymptomatic, $0.5=\mathrm{MCI} / \mathrm{MBI}, 1 \geq$ full phenotype/dementia.

${ }^{\mathrm{b}} p<0.05$ compared to asymptomatic carrier.

${ }^{c} p<0.05$ compared to asymptomatic noncarrier.

d $p<0.05$ compared to individual with $\mathrm{MCI} / \mathrm{MBI}$.

e Unless indicated otherwise, values are expressed as median (interquartile range). Other units of measure are as follows: Benson delayed recall, points; phonemic and semantic fluency, words per minute; digits forward and backward, number of digits in the largest string correctly recalled.

${ }^{\mathrm{f}}$ Volumes are expressed as mean (SD).

FTLD score 0.5 ), and $22.4 \%$ had full phenotype (CDR+NACC-FTLD score $\geq 1$ ). Median baseline plasma NfL concentrations were highest in participants with full phenotype (figure 2). There were no differences in NfL concentrations between asymptomatic mutation carriers and noncarriers for any genotype. Median plasma NfL concentrations tended to be higher in those with MBI/MCI than asymptomatic mutation carriers, but the results did not reach statistical significance $(12.2 \pm 10 \mathrm{pg} / \mathrm{mL}$ vs $7.5 \pm 6 \mathrm{pg} / \mathrm{mL}, p=0.085$, mean estimate difference $0.44,95 \%$ confidence interval $[\mathrm{CI}] 0.85-0.99, p=$ 0.016) in all genotypes combined. In C9orf 72 carriers, NfL concentrations were higher in participants with $\mathrm{MBI} / \mathrm{MCI}$ compared to asymptomatic individuals $(13.6 \pm 34 \mathrm{pg} / \mathrm{mL}$ vs $6.6 \pm 5 \mathrm{pg} / \mathrm{mL}, p<0.001$, figure 3) but not in GRN or MAPT. There were no genotype-related differences in $\mathrm{NfL}$ in asymptomatic mutation carriers or those with $\mathrm{MBI} / \mathrm{MCI}$. In full phenotype, NfL was higher in GRN $(61.5 \pm 54 \mathrm{pg} / \mathrm{mL})$ than in C9orf72 (33.9 $\pm 33 \mathrm{pg} / \mathrm{mL}, p<0.001)$ and MAPT $(20.5$ $\pm 11 \mathrm{pg} / \mathrm{mL}, p<0.001)$.

In all participants combined, a cut point of $\geq 13.6 \mathrm{pg} / \mathrm{mL}$ discriminated individuals with full phenotype from asymptomatic individuals or those with $\mathrm{MBI} / \mathrm{MCI}$ with $87.5 \%$ sensitivity, $82.7 \%$ specificity, $59.7 \%$ positive predictive value, and $96.2 \%$ negative predictive value (area under the curve [AUC] 0.901, 95\% CI 0.861-0.942, $p<0.001$ ). Plasma NfL was a poor discriminator between asymptomatic mutation carriers and those with MBI/MCI (AUC 0.676, 95\% CI $0.588-0.724, p<0.001)$, but it was a better discriminator between participants with $\mathrm{MBI} / \mathrm{MCI}$ and those with full

Figure 1 Baseline Plasma NfL Chain Concentrations by Clinical Phenotype

A

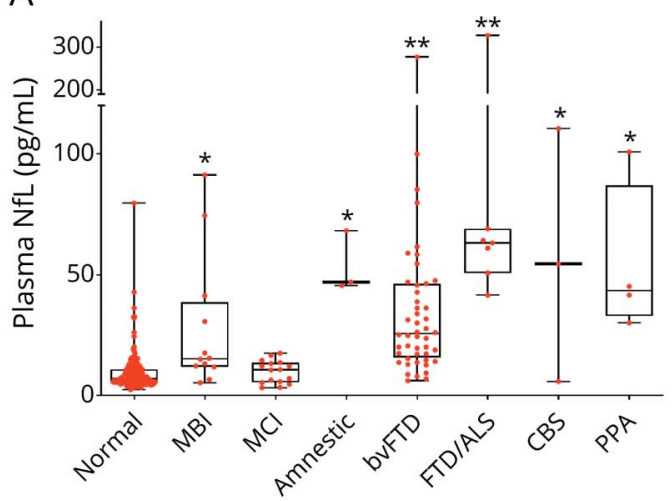

B

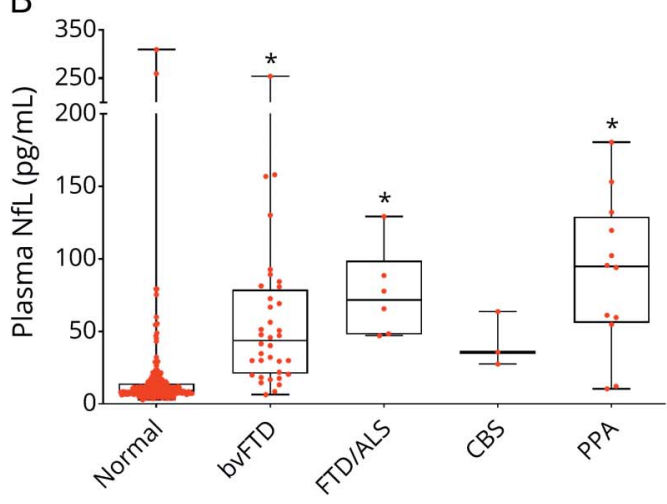

(A) Original (Longitudinal Evaluation of Familial Frontotemporal Dementia Subjects [LEFFTDS]/Advancing Research and Treatment in Frontotemporal Lobar Degeneration [ARTFL]) cohort. (B) Validation (Genetic Frontotemporal Dementia Initiative [GENFI]) cohort. Phenotypes are based on clinical diagnosis and did not rely on severity scales. Only the original cohort included clinically diagnosed prodromal disease (mild behavioral impairment [MBI] or mild cognitive impairment [MCI]). Horizontal bars represent median values. Upper and lower quartiles are delimitated by the boxes. Lowest and highest values are indicated by whiskers. bvFTD = behavioral variant frontotemporal dementia; CBS = corticobasal syndrome; FTD/ALS = frontotemporal dementia with amyotrophic lateral sclerosis; $\mathrm{NfL}=$ neurofilament light chain; PPA = primary progressive aphasia (nonfluent or semantic). ${ }^{\star C}$ Compared to normal. **Compared to normal and $\mathrm{MCl}, p<0.05$. 

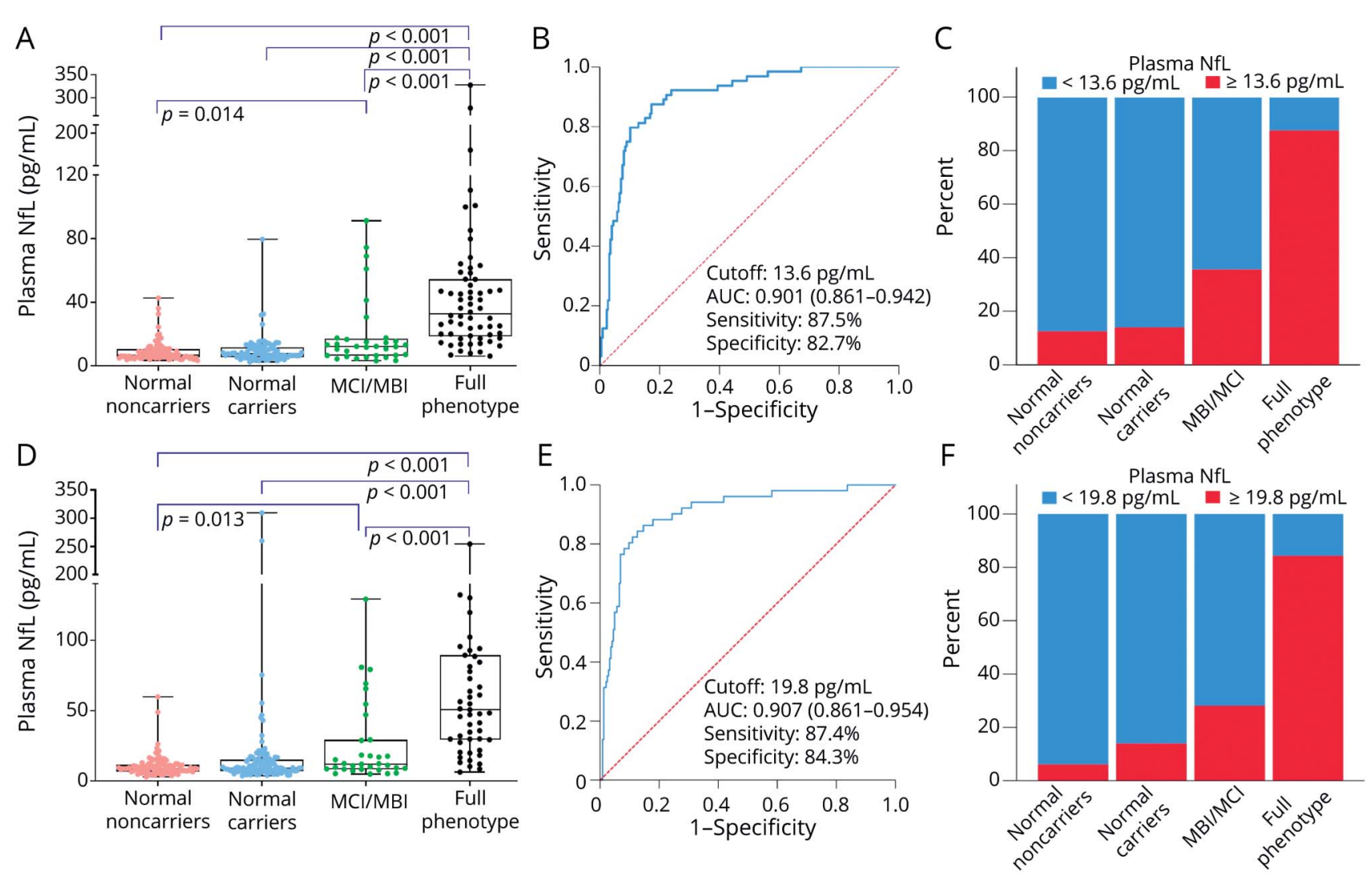

(A-C) Original (Longitudinal Evaluation of Familial Frontotemporal Dementia Subjects [LEFFTDS]/Advancing Research and Treatment in Frontotemporal Lobar Degeneration [ARTFL]) cohort. (D-F) Validation (Genetic Frontotemporal Dementia Initiative [GENFI]) cohort. Severity was determined by the CDR Dementia Staging Instrument plus Behavior and Language domains from the National Alzheimer's Disease Coordinating Center Frontotemporal Lobar Degeneration module (CDR+NACC-FTLD). (A and D) Boxplots show plasma neurofilament light chain (NfL) concentrations in asymptomatic carriers (i.e., CDR+NACC-FTLD score 0), those with mild behavioral or cognitive impairment (mild behavioral impairment/mild cognitive impairment [MBI/MCI], CDR+NACC-FTLD score 0.5), and patients with full phenotypes (CDR+NACC-FTLD score $\geq 1)$. Horizontal bars represent median values. Upper and lower quartiles are delimitated by the boxes. Lowest and highest values are indicated by whiskers. (B and E) Receiver operating characteristic (ROC) curves show that plasma NfL was a good discriminator between individuals with full phenotype and those either asymptomatic or with $\mathrm{MBI} / \mathrm{MCl}$. (C and $\mathrm{F}$ ) Proportion of patients with low or high plasma NfL concentrations, determined by the ROC curve, is presented for each disease severity. AUC = area under the curve.

phenotype $(0.803,95 \%$ CI $0.744-0.862, p<0.001)$. The proportion of participants with high $(\geq 13.6 \mathrm{pg} / \mathrm{mL}) \mathrm{NfL}$ differed by severity group: $12.2 \%$ in asymptomatic mutation noncarriers, $14.1 \%$ in asymptomatic mutation carriers, $39.4 \%$ in those with $\mathrm{MBI} / \mathrm{MCI}$, and $88.7 \%$ in those with full phenotype $\left(\chi^{2}=119.6, p<0.001\right)$.

\section{Baseline Correlations With Clinical Variables, Original Cohort}

Baseline NfL strongly correlated with age in the overall sample $(\rho=0.69,95 \%$ CI $0.505-0.695, p<0.001)$ and in asymptomatic individuals $(\rho=0.63,95 \%$ CI $0.437-0.769, p<0.001)$ and those with MBI/MCI ( $\rho=0.71,95 \%$ CI 0.364-0.917, $p<0.001)$; it correlated weakly in individuals with full phenotype $(\rho=0.23$, $95 \% \mathrm{CI}-0.109$ to $0.402, p=0.07)$. NfL concentrations were higher in women than in men $(10.7 \pm 13 \mathrm{pg} / \mathrm{mL}$ vs $7.6 \pm 9 \mathrm{pg} /$ $\mathrm{mL}$, mean estimate difference $0.75,95 \%$ CI $0.59-0.95, p=0.01$ ), even after controlling for age, disease severity, and genotype ( $\beta$ $=0.251,95 \%$ CI 0.092-0.409, $p=0.002$ ). In all participants, plasma NfL was strongly associated with all clinical, neuropsychological, and gray matter volume variables at baseline.
None of the relationships were affected by genotype, and they remained essentially unchanged after exclusion of asymptomatic noncarriers (eTable 1, doi.org/10.7272/Q6W957CZ). The strongest associations were observed with measures of disease severity, including CDR+NACC-FTLDsb, CGI-S, SEADL, and FAS scores. Weaker associations were observed with gray matter volumes. CSF biomarkers were available in 113 (40.7\%) participants (34 asymptomatic noncarriers, 46 asymptomatic mutation carriers, 14 with $\mathrm{MBI} / \mathrm{MCI}$, and 19 with full phenotype). Plasma NfL correlated with CSF NfL $(\rho=0.74, p<0.001)$, CSF p-NfH $(\rho=0.73, p<0.001)$, and CSF tau $(\rho=0.45, p<0.001)$, but not with CSF neurogranin $(\rho=0.06, p=0.94)$ or CSF $p$-tau $(\rho=0.07, p=0.46)$. There were no differences in the proportion of $A P O E$ carriers as a function of clinical phenotype, genotype, or disease severity or differences in NfL concentrations by APOE genotype.

\section{Baseline NfL, Phenoconversion, and Disease Progression, Original Cohort}

Twenty-six mutation carriers phenoconverted after 2 years ( 15 asymptomatic [12 to MBI/MCI and 3 to full phenotype] and 


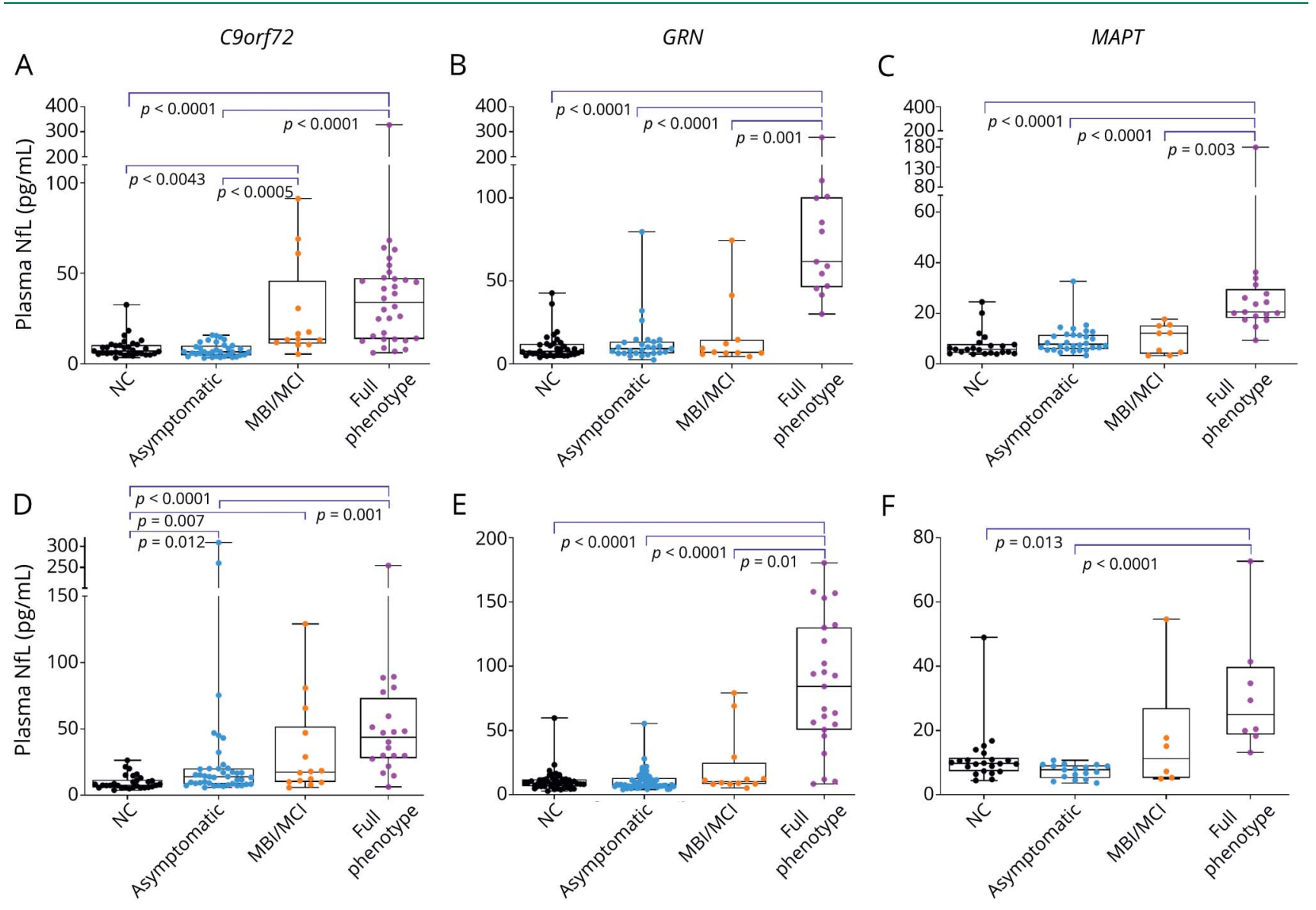

(A-C) Original cohort. (D-F) Validation cohort. $\mathrm{MBI} / \mathrm{MCI}=$ mild behavioral or cognitive impairment (CDR Dementia Staging Instrument plus Behavior and Language domains from the National Alzheimer's Disease Coordinating Center Frontotemporal Lobar Degeneration module score 0.5 ); $C 90$ rf $72=$ chromosome 9 open reading frame 72; GRN = progranulin; MAPT = microtubule-associated protein tau; NC = noncarrier; NfL = neurofilament light chain.

$11 \mathrm{MBI} / \mathrm{MCI}$ to full phenotype). Phenoconversion occurred in 10 of $21(47.6 \%)$ of asymptomatic or $\mathrm{MBI} / \mathrm{MCI}$ mutation carriers with baseline $\mathrm{NfL} \geq 13.6 \mathrm{pg} / \mathrm{mL}$ compared to 16 of 84 (11.4\%) of those with baseline NfL $<13.6 \mathrm{pg} / \mathrm{mL}(p=0.007)$. Median baseline NfL concentrations were higher in asymptomatic mutation carriers who phenoconverted to either MBI/ MCI or dementia over the next 2 years compared to those who remained asymptomatic $(11.4 \pm 7 \mathrm{pg} / \mathrm{mL}$ vs $6.7 \pm 5 \mathrm{pg} / \mathrm{mL}, p=$ 0.002 , figure 4). Plasma NfL concentrations were also higher in asymptomatic mutation carriers whose CDR+NACC-FTLDsb scores progressed by 1 point, even in the absence of phenoconversion $(10.8 \pm 8 \mathrm{pg} / \mathrm{mL})$, compared to those whose scores remained stable $(6.6 \pm 3 \mathrm{pg} / \mathrm{mL}, p=0.0017$, data available from Dryad, efigure 1, doi.org/10.7272/Q6W957CZ).

\section{Asymptomatic Mutation Carriers}

As a continuous variable, baseline NfL related to future decline in CDR+NACC-FTLDsb, CGI-S, and FAS scores (table 2 ). For example, every baseline log NfL $1 \mathrm{pg} / \mathrm{mL}$ in asymptomatic mutation carriers was associated with a 1.6-point increase in CDR+NACC-FTLDsb score at year 1 (95\% CI $0.75-2.6, p<0.001)$ and a 2.5 -point increase at year $2(95 \%$ CI 1.6-3.4, $p<0.001)$. Similar results were observed when
NfL was analyzed as a categorical variable. For example, asymptomatic mutation carriers with high $(\geq 13.6 \mathrm{pg} / \mathrm{mL})$ baseline NfL had CDR+NACC-FTLDsb scores were 1.6 points higher at 1 year (95\% CI 1.0-2.2, $p<0.001)$ and 2.4 points higher at 2 years (95\% CI 1.8-3.0, $p<0.001)$ than those with low baseline NfL (figure 5). High NfL also related to lower frontal and temporal brain volumes after 2 years. NfL did not predict change in any of the clinical scales or brain volumes in mutation noncarriers.

\section{Individuals With $\mathrm{MBI} / \mathrm{MCI}$}

In mutation carriers with $\mathrm{MBI} / \mathrm{MCI}$ at baseline (CDR+NACC-FTLD score 0.5 ), baseline NfL was strongly associated with decline at year 2 on CDR+NACC-FTLDsb, MoCA, SEADL, FAS, California Verbal Learning Test immediate recall, Benson recall, digits forward, and semantic fluency scores, but not in brain volumes (table 2).

\section{Full Phenotype}

In mutation carriers with full phenotype (CDR+NACCFTLD score $\geq 1$ ), baseline NfL related to decline in CDR+NACC-FTLDsb, MoCA, and SEADL phonemic fluency scores and brain volume composites after 2 years (table 2). 


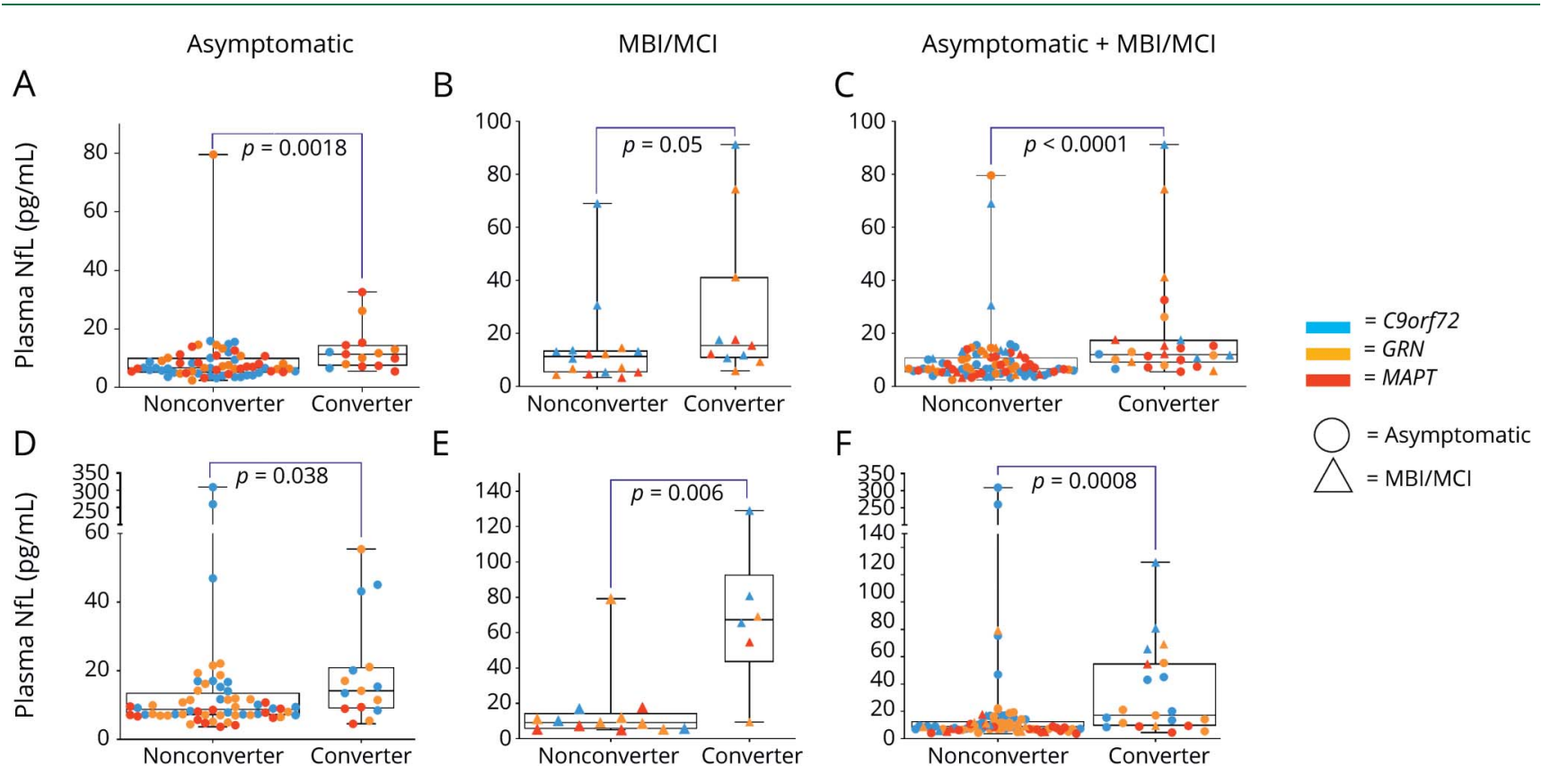

Severity was determined with the CDR Dementia Staging Instrument plus Behavior and Language domains from the National Alzheimer's Disease Coordinating Center Frontotemporal Lobar Degeneration module (CDR+NACC-FTLD). (A-C) Original (Longitudinal Evaluation of Familial Frontotemporal Dementia Subjects [LEFFTDS]/Advancing Research and Treatment in Frontotemporal Lobar Degeneration [ARTFL]) cohort. (D-F) Validation (Genetic Frontotemporal Dementia Initiative [GENFI]) cohort. (A and D) Median baseline neurofilament light chain (NfL) concentrations were higher in asymptomatic mutation carriers (CDR+NACCFTLD score 0 ) who progressed to either mild behavioral or cognitive impairment (MBI/MCl; CDR+NACC-FTLD score 0.5) or full phenotype (CDR+NACC-FTLD score $\geq 1$ ) on follow-up. (B and E) A similar trend was observed in individuals who had $\mathrm{MBI} / \mathrm{MCl}$ at baseline and when all participants (asymptomatic mutation carriers and those with $\mathrm{MBI} / \mathrm{MCl}$ ) were combined ( $\mathrm{C}$ and $\mathrm{F}$ ). Horizontal bars represent median values. Upper and lower quartiles are delimitated by the boxes. Lowest and highest values are indicated by whiskers. Circles = asymptomatic; triangles = MBI/MCl; blue = chromosome 9 open reading frame 72 (C9orf72) mutation carriers; red = microtubule-associated protein tau (MAPT) mutation carriers; yellow = progranulin $(G R N)$ mutation carriers; .

\section{Validation Cohort}

In the validation cohort, of 297 participants with baseline evaluations, 189 (63.6\%) had follow-up year 1 data (available in Dryad, eTable 2, doi.org/10.7272/Q6W957CZ). Plasma $\mathrm{NfL}$ concentrations were higher in all symptomatic mutation carriers compared to asymptomatic participants except for CBS (figure 1). Median baseline plasma NfL concentrations were higher in participants with full phenotype (50.6 $\pm 59 \mathrm{pg}$ / $\mathrm{mL})$ compared to asymptomatic mutation noncarriers $(8.8 \pm$ $5 \mathrm{pg} / \mathrm{mL})$, asymptomatic mutation carriers $(9.1 \pm 8 \mathrm{pg} / \mathrm{mL})$, and those with MBI/MCI $(12.1 \pm 20 \mathrm{pg} / \mathrm{mL}, p<0.001)$ (figure 2). A cut point of $\geq 19.8 \mathrm{pg} / \mathrm{mL}$ discriminated those with full phenotype from asymptomatic individuals or those with $\mathrm{MBI} / \mathrm{MCI}$ with $87.4 \%$ sensitivity, $84.3 \%$ specificity, $58.1 \%$ positive predictive value, and $96.4 \%$ negative predictive value (AUC 0.907, 95\% CI 0.861-0.954, $p<0.001$ ). This cut point was also a fair discriminator between $\mathrm{MBI} / \mathrm{MCI}$ and full phenotype (AUC 0.805, 95\% CI 0.704-0.906) but not between asymptomatic mutation carriers and those with $\mathrm{MBI} /$ MCI (AUC 0.641, 95\% CI 0.530-0.752). The proportion of participants with high $(\geq 19.8 \mathrm{pg} / \mathrm{mL}) \mathrm{NfL}$ was different in each disease severity group $(6.1 \%$ in asymptomatic mutation noncarriers, $13.9 \%$ in asymptomatic mutation carriers, $28.1 \%$ in those with $\mathrm{MBI} / \mathrm{MCI}$, and $84.3 \%$ in individuals with full phenotype, $\left.\chi^{2}=122.6, p<0.001\right)$. In the whole cohort or in mutation carriers only, baseline plasma NfL correlated with
CDR+NACC-FTLDsb score, MMSE score, and all neuropsychological measures (eTable 2, doi.org/10.7272/ Q6W957CZ).

Twenty-one mutation carriers phenoconverted after 1 year ( 15 asymptomatic individuals [13 to $\mathrm{MBI} / \mathrm{MCI}$ and 2 to full phenotype] and 6 with $\mathrm{MBI} / \mathrm{MCI}$ to full phenotype). Plasma NfL concentrations were higher in phenoconverters than nonphenoconverters in asymptomatic mutation carriers $(14.1 \pm 12$ $\mathrm{pg} / \mathrm{mL}$ vs $8.7 \pm 6 \mathrm{pg} / \mathrm{mL}, p=0.038)$ and those with $\mathrm{MBI} / \mathrm{MCI}$ $(67.3 \pm 49 \mathrm{pg} / \mathrm{mL}$ vs $9.0 \pm 8 \mathrm{pg} / \mathrm{mL}, p=0.006)$ (figure 4). Plasma NfL concentrations were also higher in asymptomatic mutation carriers whose CDR+NACC-FTLDsb scores progressed by 1 point, even in the absence of phenoconversion $(15.3 \pm 33 \mathrm{pg} / \mathrm{mL})$ compared to those whose scores remained stable ( $8.9 \pm 7 \mathrm{pg} / \mathrm{mL}, p=0.014$, efigure 1, doi.org/10.7272/ Q6W957CZ). In asymptomatic mutation carriers, baseline NfL predicted worsening at year 1 in CDR+NACC-FTLDsb, MMSE, and Trail-Making Test Part A scores. In participants with $\mathrm{MBI} / \mathrm{MCI}$, baseline NfL predicted decline at year 1 in CDR+NACC-FTLDsb, MMSE, Trail-Making Test Part B, and phonemic fluency scores. In those with full phenotype, baseline NfL was associated with subsequent decline in MMSE and Trail-Making Test Part A scores, but the relationships did not survive correction for multiple comparisons (available in Dryad, eTable 3). 
Table 2 Prediction of Disease Progression at 2 Years by Plasma NfL in FTLD-Causing Mutation Carriers, Original Cohort

\begin{tabular}{|c|c|c|c|c|c|c|}
\hline & \multicolumn{6}{|c|}{ NfL (as a Continuous Variable) $\times$ Time } \\
\hline & \multicolumn{2}{|l|}{ Asymptomatic } & \multicolumn{2}{|l|}{$\mathrm{MBI} / \mathrm{MCl}$} & \multicolumn{2}{|l|}{ Full Phenotype } \\
\hline & Estimate $^{a}$ & $p$ Value & Estimate $^{a}$ & $p$ Value & Estimate $^{a}$ & $p$ Value \\
\hline CDR+NACC-FTLDsb score & 2.5 (1.6 to 3.4$)$ & $<0.001$ & 6.4 (3.5 to 9.4$)$ & $<0.001$ & 6.9 (2.6 to 11.2$)$ & 0.002 \\
\hline MoCA score & $-2.3(-0.01$ to -4.5$)$ & $0.049^{b}$ & $-14.7(-21.3$ to -8.1$)$ & $<0.001$ & $-13.2(-21.3$ to -5.2$)$ & 0.002 \\
\hline UPDRS score & $0.4(-1.0$ to 1.9$)$ & 0.56 & $7.1(-0.3$ to 14.7$)$ & 0.06 & $4.4(-16.5$ to 25.5$)$ & 0.6 \\
\hline CGI-S score & 1.2 (0.7 to 1.7$)$ & $<0.001$ & $1.2(0.1$ to 2.5$)$ & 0.07 & 1.7 (0.4 to 3.0$)$ & 0.01 \\
\hline SEADL score & $-2.8(-15.2$ to 9.4$)$ & 0.6 & $-38.8(-65$ to 12.7$)$ & 0.004 & $-21.0(-51.5$ to 9.4$)$ & 0.1 \\
\hline FAS score & $5.0(2.7$ to 7.3$)$ & $<0.001$ & $12.2(5.8$ to 18.5$)$ & $<0.001$ & $-0.8(-14.6$ to 16.2$)$ & 0.9 \\
\hline NPI score & $0.8(-1.8$ to 3.5$)$ & 0.5 & $-1.3(-6.5$ to 3.7$)$ & 0.5 & $-3.0(-14.1$ to 7.5$)$ & 0.5 \\
\hline CVLTi, score & $-1.7(-3.5$ to 0.1$)$ & 0.07 & $-3.8(-6.6$ to -1.0$)$ & 0.009 & $-2.2(-6.1$ to 1.6$)$ & 0.2 \\
\hline CVLTd, score & $-1.4(-3.3$ to -0.3$)$ & 0.1 & $-2.6(-5.8$ to 0.4$)$ & 0.09 & $-2.0(-5.8$ to 1.7$)$ & 0.2 \\
\hline Benson recall score & $-0.4(-1.6$ to 0.8$)$ & 0.4 & $-5.7(-8.6$ to -2.9$)$ & $<0.001$ & $-2.3(-9.6$ to 4.9$)$ & 0.5 \\
\hline Digits forward score & $-1.0(-2.1$ to 0.1$)$ & 0.09 & $-2.4(-4.1$ to -0.7$)$ & 0.005 & $-1.4(-4.6$ to 1.7$)$ & 0.3 \\
\hline Digits backward score & $-1.0(-2.3$ to 0.1$)$ & 0.07 & $-0.9(-2.3$ to 0.4$)$ & 0.1 & $-1.6(-4.2$ to 0.9$)$ & 0.2 \\
\hline Trail-Making Test Part A score & $3.7(-11.2$ to 18.7$)$ & 0.6 & $1.3(-8.5$ to 11.1$)$ & 0.7 & $-8.8(-21.5$ to 3.7$)$ & 0.16 \\
\hline Trail-Making Test Part B score & $31.6(-78$ to 15$)$ & 0.18 & $4.9(-43$ to 53$)$ & 0.8 & 41 ( -25 to 107$)$ & 0.2 \\
\hline Phonemic fluency score & $-0.8(-4.7$ to -3.0$)$ & 0.002 & $-1.9(-7.0$ to 3.1$)$ & 0.4 & $-2.3(-2.1$ to 6.8$)$ & 0.3 \\
\hline Semantic fluency score & $-2.4(-7.0$ to 2.0$)$ & 0.2 & $-8.2(-14.4$ to -2.1$)$ & 0.009 & $-9.6(-16.5$ to -2.7$)$ & 0.007 \\
\hline Left frontal & $-3,786(-5,848$ to -1723$)$ & $<0.001$ & $-979(-4,933$ to 2,974$)$ & 0.5 & $-11349(-19,842$ to $-2,856)$ & 0.012 \\
\hline Right frontal & $-2,460(-4,422$ to -498$)$ & 0.01 & $-949(-4,866$ to 2,967$)$ & 0.4 & $-2,159(-12,400$ to 8,081$)$ & 0.6 \\
\hline Left temporal & $-1797(-3,104$ to -491$)$ & 0.008 & $-237(-2,377$ to 1,903$)$ & 0.8 & $-7,874(-13,555$ to $-2,194)$ & 0.01 \\
\hline Right temporal & $-1,468(-2,419$ to -516$)$ & 0.003 & $92(-1715$ to 1,900$)$ & 0.9 & $0.1(-6,748$ to 6,748$)$ & 1.0 \\
\hline
\end{tabular}

Abbreviations: CDR+NACC-FTLDsb = CDR Dementia Staging Instrument plus Behavior and Language domains from the National Alzheimer's Disease Coordinating Center Frontotemporal Lobar Degeneration module sum of boxes score; CGI-S = Clinical Global Impression of Severity; CVLTd = California Verbal Learning Test, Short Form-delayed recall; CVLTi = California Verbal Learning Test, Short Form-immediate recall; FAS = Functional Assessment Scale; FTLD = frontotemporal lobar degeneration; IQR = interquartile range; $\mathrm{MBI} / \mathrm{MCI}=$ mild behavioral/cognitive impairment; MoCA = Montreal Cognitive Assessment; NfL = plasma neurofilament-light chain; NPI = Neuropsychiatric Inventory; SEADL = Schwab and England Activities of Daily Living; UPDRS = Unified Parkinson's Disease Rating Scale, motor section.

Estimates, 95\% confidence intervals and $p$ values are presented for the interaction of $\mathrm{NfL}$ with time as predictors or each of the clinical variables.

a Estimates represent the predicted change in absolute values in each scale, neuropsychological test, or composite volume per increase in 1 log concentration unit in plasma neurofilament light chain at each time point (fixed effect).

${ }^{b}$ Did not survive correction for multiple comparisons within that severity level.

\section{Discussion}

We analyzed the prognostic value of plasma Nfl concentrations in carriers of the most common FTLD-causing mutations, C9orf72, GRN, and MAPT, over 1-2 years of follow-up, with a special emphasis on asymptomatic mutation carriers and carriers with prodromal disease (MBI/MCI). In 2 independent cohorts, plasma NfL concentrations were strongly related to disease severity with stepwise increases from asymptomatic (clinically normal) through MBI/MCI to full phenotype. At baseline, plasma NfL was strongly correlated with global and functional status, neuropsychological scores, and brain volume. Higher baseline NfL was associated with greater disease severity after 1 or 2 years of follow-up, regardless of disease severity and genotype. Remarkably, this included asymptomatic mutation carriers, in whom plasma $\mathrm{NfL}$ was also associated with future clinical decline, allowing identification of individuals at high risk for phenoconversion to symptomatic status within 2 years. Consistent with this finding, NfL also predicted worse clinical and neuropsychological status or more brain atrophy, regardless of disease severity and genotype. These results suggest a role for plasma NfL as a prognostic biomarker in $\mathrm{f}$ FTLD.

The findings in our original and validation cohorts are consistent with previous studies of serum NfL in f-FTLD and sporadic FTLD. In f-FTLD, serum NfL is associated with disease severity, brain volume, and brain atrophy. ${ }^{18}$ In symptomatic 

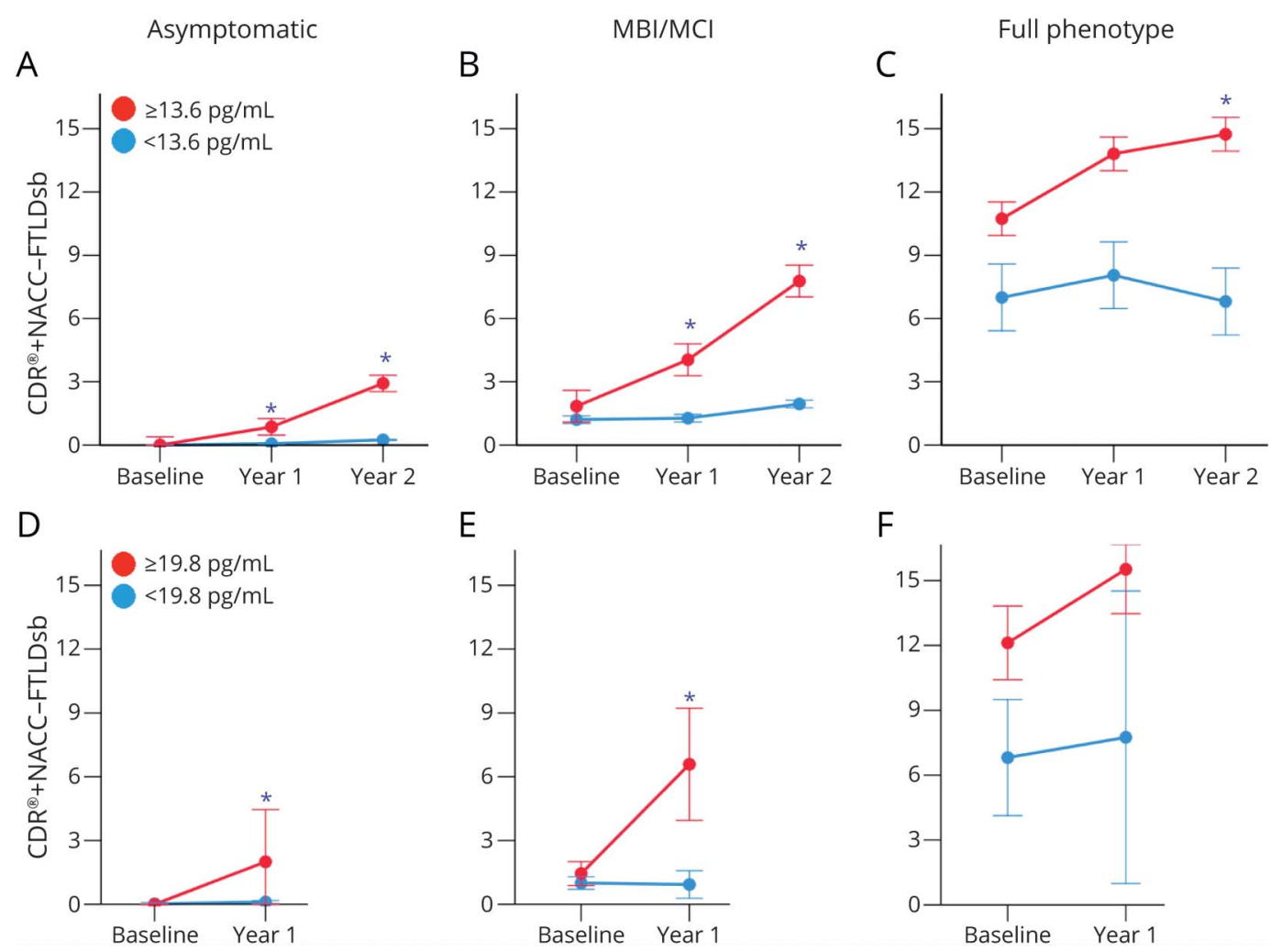

(A-C) Original (Longitudinal Evaluation of Familial Frontotemporal Dementia Subjects [LEFFTDS]/Advancing Research and Treatment in Frontotemporal Lobar Degeneration [ARTFL) cohort. (D-F) Validation (Genetic Frontotemporal Dementia Initiative [GENFI]) cohort. Figure shows the results of models using data from al genotypes in each severity group. In the original cohort, patients with high (red; $\geq 13.6 \mathrm{pg} / \mathrm{mL}$ ) baseline plasma neurofilament light chain (NfL) showed worse clinical scores at 2 years compared to patients with low (blue; $<13.6 \mathrm{pg} / \mathrm{mL}$ ) NfL, which was supported by NfL level-by-time interaction. This differential predictive effect by NfL level was observed regardless of disease severity, including asymptomatic carriers. Similar results were observed in the validation cohort with a cut point value of $19.8 \mathrm{pg} / \mathrm{mL}$. CDR+NACC-FTLDsb = CDR Dementia Staging Instrument plus Behavior and Language domains from the National Alzheimer's Disease Coordinating Center Frontotemporal Lobar Degeneration module sum of boxes score. *Between-group contrast at that time point, $p<0.05$.

sporadic FTLD, baseline serum NfL correlated with executive function and brain atrophy, but not with longitudinal change in neuropsychological scores, ${ }^{17}$ which is similar to what we observed in participants with full phenotype. This study and others $^{18,22,35}$ found that in fully symptomatic patients, GRN mutation carriers had higher NfL concentrations than C9or72 and MAPT mutation carriers. This does not seem to be due to differences in the number of participants by genotype or the age of symptomatic participants in each genetic group and may reflect a faster rate of neurodegeneration in symptomatic GRN mutation carriers. Consistent with previous studies, we observed baseline NfL differences between symptomatic and asymptomatic FTLD mutation carriers and between phenoconverters and nonconverters. ${ }^{35}$ Similar to those studies, we also observed a large within-group variability in NfL concentrations, regardless of clinical phenotype, disease severity, or genotype. This variability likely explains why median NfL concentrations in asymptomatic mutation carriers were not elevated, yet high concentrations were still associated with future clinical progression. In this group, NfL showed good negative predictive value but poor positive predictive value for phenoconversion. The absolute cutoff values for discrimination between asymptomatic and symptomatic participants were similar to those reported in previous studies based on data from our validation cohort. ${ }^{17,18,35}$ However, 1 study reported a higher cutoff $(33 \mathrm{pg} / \mathrm{mL})^{17}$ that may be explained by the inclusion of older controls and sporadic cases compared to the familial cases reported here. ${ }^{36}$

Unlike previous studies, we used the CDR+NACC-FTLD score to stratify patients by level of global impairment, allowing delineation of $\mathrm{MBI} / \mathrm{MCI}$, a prodromal state of mild or questionable disease between asymptomatic and full phenotype. The CDR+NACC-FTLD score is more appropriate for patients with FTLD and superior to relying on the clinical phenotype or the traditional Clinical Dementia Rating because the CDR+NACC-FTLD includes measures of behavioral and language impairment. ${ }^{37}$ We found that baseline NfL concentrations in asymptomatic and $\mathrm{MBI} / \mathrm{MCI}$ mutation carriers best predicted changes in global and functional scales (i.e., CDR+NACC-FTLDsb, CGI-S, and FAS). In addition, $\mathrm{NfL}$ predicted declines in activities of daily living, as measured by the SEADL and FAS scales and several neuropsychological tests, in individuals with $\mathrm{MBI} / \mathrm{MCI}$, but not in asymptomatic mutation carriers or full phenotype. The severity-dependent differences in predictive value of baseline NfL are probably 
attributable to a number of factors. These include a faster rate of functional decline in $\mathrm{MBI} / \mathrm{MCI}$, differences in the duration of the MBI/MCI stage depending on the phenotype, and absence of activities of daily living impairments in asymptomatic individuals and a ceiling effect for deterioration in fully symptomatic individuals. Identification of individuals with $\mathrm{MBI} / \mathrm{MCI}$, however, may be challenging. The sample sizes for $\mathrm{MBI} / \mathrm{MCI}$ in both cohorts of this study were relatively small, and the follow-up durations were limited. This may explain why differences in baseline NfL concentrations in participants with $\mathrm{MBI} / \mathrm{MCI}$ by conversion status were not as strong compared to differences between those with $\mathrm{MBI}$ / MCI and asymptomatic or fully symptomatic mutation carriers. These observations might also reflect a short duration in the MBI/MCI state and fluctuation in clinical status over time, with some participants with $\mathrm{MBI} / \mathrm{MCI}$ progressing to full phenotype and others returning to asymptomatic status. The additional follow-up data that will be collected as part of the ongoing ARTFL LEFFTDS Longitudinal Frontotemporal Dementia (ALLFTD) study ${ }^{38}$ will improve the understanding of the clinical value of plasma NfL in prodromal f-FTLD.

Our results suggest that plasma NfL may be a promising endpoint for FTLD clinical trials. A variety of therapies that target the underlying pathologic proteins encoded by the 3 FTLDcausing genes studied here are entering clinical trials for $f$ FTLD. ${ }^{7}$ The ultimate goal for these therapies is to prevent disease onset in mutation carriers. A major challenge for testing the efficacy of such interventions is the inability to measure clinically meaningful endpoints in asymptomatic individuals who are at risk for disease. Recent US Food and Drug Administration guidance on developing therapeutics for presymptomatic or early Alzheimer disease suggests that therapies might be approved under an accelerated mechanism on the basis of a biomarker that is "reasonably likely to predict clinical benefit." ${ }^{39}$ Our data show associations between plasma NfL concentrations and subsequent functional status, which are considered inherently clinically meaningful, within 2 years of follow-up. Therefore, plasma NfL might be used as a continuous variable endpoint (difference in mean NfL concentration in placebo vs intervention arm) or as a time-to-event endpoint (delay in onset of the sharp rise in NfL that occurs at the transition from the asymptomatic to symptomatic phase of disease). Such an approach was previously used for drugs to treat macular degeneration that were approved for marketing by using optical coherence tomography measurements as endpoints that are highly predictive of future declines in visual acuity. ${ }^{40}$

Our study has limitations. NfL is not a pathophysiology-specific biomarker of FTLD, and its elevations in a number of general conditions render it a nonspecific marker of neuronal injury. Future projects should aim at identifying and deploying specific markers of disease activity and severity in FTLD, and we have previously reported the comparative diagnostic value of plasma NfL vs plasma p-tau in FTLD and Alzheimer disease. ${ }^{41}$ On the basis of work in dominantly inherited Alzheimer disease, ${ }^{42}$ longitudinal plasma NfL measurements may have better predictive ability for clinical decline than the cross-sectional measures we used. Longitudinal plasma samples of participants of the LEFFTDS and ARTFL projects are being collected, and future projects will examine longitudinal $\mathrm{NfL}$ concentrations and their relationship with disease progression. Finally, we found no influence of the APOE genotype on NfL concentrations or predictive ability. The analyses, however, did not examine other potential genetic risk factors such as polymorphisms within $M_{A P T}{ }^{43}{ }^{T M E M 106 B},{ }^{44}$ or $E G F R^{45}$ that have been identified as potential modulators of FTLD risk.

This study adds to a large body of evidence supporting plasma $\mathrm{NfL}$ as a useful prognostic biomarker for syndromes associated with FTLD. ${ }^{12,14,17,35,46,47}$ By demonstrating the ability to identify asymptomatic FTLD mutation carriers at risk of progression to symptomatic status over 2 years, our findings provide a strong rationale for developing this biomarker as a potential inclusion criterion or endpoint for prevention studies in asymptomatic f-FTLD mutation carriers.

\section{Acknowledgment}

The authors acknowledge the invaluable contributions of the participants and their families in ARTFL, LEFFTDS, and GENFI, as well as the assistance of the support staffs at each of the participating sites. They extend their appreciation to Drs. John Hsiao and Dallas Anderson from the National Institute on Aging and Dr. Margaret Sutherland from the National Institute of Neurological Disorders and Stroke. The manuscript has been reviewed by the ALLFTD Publications Committee for scientific content. Daniel I. Kaufer, MD, is deceased.

\section{Study Funding}

ALLFTD Consortium (LEFFTDS: U01 AG045390; ARTFL: U54 NS092089; ALLFTD: U19AG063911). J.C.R is supported by National Institute on Aging-NIH: K23AG059888. AMS is supported by National Institute on Aging-NIH: K23AG061253 and Larry L. Hillblom Foundation: 2018-A025-FEL. Work was also supported by grants U24 AG021886 and U01 AG016976 and the Bluefield Project to Cure FTD. Samples from the National Centralized Repository for Alzheimer's Disease and Related Dementias, which receives government support under a cooperative agreement grant (U24 AG21886), were used in this study. The Dementia Research Centre is supported by Alzheimer's Research UK, Alzheimer's Society, Brain Research UK, and The Wolfson Foundation. This work was supported by the National Institute for Health Research UCL/H Biomedical Research Centre, the Leonard Wolfson Experimental Neurology Centre Clinical Research Facility, and the UK Dementia Research Institute, which receives its funding from UK DRI Ltd, funded by the UKMedical Research Council, Alzheimer's Society, and Alzheimer's Research UK. J.D.R. is supported by a Medical Research Council Clinician Scientist Fellowship (MR/M008525/1) and has received funding from the National Institute for Health Research Rare Disease Translational Research Collaboration (BRC149/ NS/MH). R.C. and C.G. are supported by Frontotemporal Dementia Research Studentships in Memory of David 
Blechner funded through The National Brain Appeal (RCN 290173). M.B. is supported by a Fellowship award from the Alzheimer's Society, UK (AS-JF-19a-004-517) and by the UK Dementia Research Institute, which receives its funding from DRI Ltd, funded by the UK Medical Research Council, Alzheimer's Society, and Alzheimer's Research UK. R.L. is supported by the Canadian Institutes of Health Research and the Chaire de Recherche sur les Aphasies Primaires Progressives Fondation Famille Lemaire. C.G. is supported by the Swedish Frontotemporal Dementia Initiative Schörling Foundation, Swedish Research Council, JPND Prefrontals, 2015-02926, 2018-02754, Swedish Alzheimer Foundation, Swedish Brain Foundation, Karolinska Institutet Doctoral Funding, KI StratNeuro, Swedish Dementia Foundation, and Stockholm County Council ALF/Region Stockholm. J.L. is supported by Germany's Excellence Strategy within the framework of the Munich Cluster for Systems Neurology (German Research Foundation, EXC 2145 SyNergy 390857198). This work was also supported by the Medical Research Council UK GENFI grant (MR/M023664/1), the Bluefield Project, the National Institute for Health Research including awards to Cambridge and UCL Biomedical Research Centres, and the JPND GENFI-PROX grant (2019-02248). Several authors of this publication are members of the European Reference Network for Rare Neurologic Diseases, project No. 739510. J.B.R is supported by NIHR Cambridge Biomedical Research Centre (BRC-1215-20014).

\section{Disclosure}

J.C. Rojas is a site principal investigator for clinical trials supported by Eli Lilly and receives support from NIH. P. Wang reports no disclosures relevant to the manuscript. A.M. Staffaroni receives support from the Larry L. Hillblom Foundation and NIH. C. Heller, Y. Cobigo, A. Wolf, S.M. Goh, P.A. Ljubenkov, H.W. Heuer, J.C. Fong reports no disclosures relevant to the manuscript, and J.B. Taylor report no disclosures relevant to the manuscript. E. Veras and L. Song are Quanterix employees. A. Jeromin is an advisor to Quanterix. D. Hanlon is a Quanterix employee. L. Yu, A. Khinikar, R. Sivasankaran, and A. Kieloch are Novartis employees. M.A. Valentin is a Novartis employee and shareholder. A.M. Karydas, L.L. Mitic, R. Pearlman, and J. Kornak report no disclosures relevant to the manuscript. J.H. Kramer receives research support from NIH. B.L. Miller receives research support from NIH and the Bluefield Project to Cure FTD. K. Kantarci served on the Data Safety Monitoring Board for Takeda Global Research \& Development Center, Inc and data monitoring boards of Pfizer and Janssen Alzheimer Immunotherapy and reports research support from Avid Radiopharmaceuticals, Eli Lilly, the Alzheimer's Drug Discovery Foundation, and NIH. D.S. Knopman serves on the Data Safety Monitoring Board of the DIAN-TU study; is a site principal investigator for clinical trials sponsored by Biogen, Lilly, and the University of Southern California; and is funded by NIH. N. Graff-Radford receives royalties from UpToDate and has participated in multicenter therapy studies by sponsored by Biogen, TauRx, AbbVie, Novartis, and Lilly. He receives research support from NIH. L. Petrucelli receives research support from NIH. R. Rademakers receives research funding from NIH and the Bluefield Project to Cure Frontotemporal Dementia. D.C. Irwin receives support from NIH, Brightfocus Foundation, and Penn Institute on Aging. M. Grossman receives grant support from NIH, Avid, and Piramal; participates in clinical trials sponsored by Biogen, TauRx, and Alector; serves as a consultant to Bracco and UCB; and serves on the Editorial Board of Neurology ${ }^{\circledR}$. E.M. Ramos reports no disclosures relevant to the manuscript. G. Coppola receives research support from NIH. M.F. Mendez and Y. Bordelon report no disclosures relevant to the manuscript. B.C. Dickerson receives research support from NIH. N. Ghoshal has participated or is currently participating in clinical trials of antidementia drugs sponsored by the following companies: Bristol Myers Squibb, Eli Lilly/Avid Radiopharmaceuticals, Janssen Immunotherapy, Novartis, Pfizer, Wyeth, SNIFF (Study of Nasal Insulin to Fight Forgetfulness) study, and A4 (Anti-Amyloid Treatment in Asymptomatic Alzheimer's Disease) trial. She receives research support from Tau Consortium and Association for Frontotemporal Dementia and is funded by NIH. E.D. Huey receives research support from NIH. I.R. Mackenzie receives research funding from Canadian Institutes of Health Research. B.S. Appleby reports no disclosures relevant to the manuscript. K. DomotoReilly serves or has served as an investigator for clinical trials sponsored by Avid Radiopharmaceuticals, Biogen, and Janssen Pharmaceuticals; has served as Advisory Board consultant for Biogen; and receives research support from NIH. G.R. Hsiung has served as an investigator for clinical trials sponsored by AstraZeneca, Eli Lilly, and Roche/Genentech. He receives research support from Canadian Institutes of Health Research and the Alzheimer Society of British Columbia. A.W. Toga receives research support from the NIH and the Alzheimer's Association. S. Weintraub receives research support from NIH. D.I. Kaufer is deceased; disclosures are not included for this author. D. Kerwin, I. Litvan, and C.U. Onyike report no disclosures relevant to the manuscript. A. Pantelyat receives grant support from the NIH. E.D. Roberson receives research funding from the Bluefield Project to Cure FTD. M.C. Tartaglia and T. Foroud report no disclosures relevant to the manuscript. W. Chen, J. Czerkowicz, and D.L. Graham are Biogen employees. J.C. van Swieten, B. Borroni, R. Sanchez-Valle, F. Moreno, R. Laforce, C. Graff, M. Synofzik, and D. Galimberti report no disclosures relevant to the manuscript. J.B. Rowe reports consultancy for Asceneuron, Biogen, UCB, and SV Healthcare and research grants from Janssen, Lilly, and AZ-Medimmune. M. Masellis, E. Finger, R. Vandenberghe, A. de Mendonça, F. Tagliavini, I. Santana, S. Ducharme, C.R. Butler, and A. Gerhard report no disclosures relevant to the manuscript. J. Levin reports speakers fees from Bayer Vital, consulting fees from Axon Neuroscience, nonfinancial support from Abbvie, compensation for part time CMO from MODAG, author fees from Thieme medical publishers and from W. Kohlhammer GbmH medical publishers, all outside the submitted work. A. Danek, M. Otto, S. Sorbi, D.M, Cash, R.S. Convery, M. Bocchetta, M. Foiani, 
C.V. Greaves, G. Peakman, L. Russell, I. Swift, and E. Todd report no disclosures relevant to the manuscript. J.D. Rohrer has served as a consultant for Biogen, Ionis, Alector, Wave Life Sciences, and Astex. B.F. Boeve has served as an investigator for clinical trials sponsored by Axovant and Biogen. He receives royalties from the publication of Behavioral Neurology of Dementia (Cambridge Medicine, 2009, 2017). He serves on the Scientific Advisory Board of the Tau Consortium. He receives research support from NIH, the Mayo Clinic Dorothy and Harry T. Mangurian Jr. Lewy Body Dementia Program, and the Little Family Foundation. H.J. Rosen has received research support from Biogen Pharmaceuticals, has consulting agreements with Wave Neuroscience and Ionis Pharmaceuticals, and receives research support from NIH. A.L. Boxer receives research support from NIH, the Tau Research Consortium, the Association for Frontotemporal Degeneration, the Bluefield Project to Cure Frontotemporal Dementia, Corticobasal Degeneration Solutions, the Association for Frontotemporal Degeneration, and the Alzheimer's Association. He has served as a consultant for Abbvie, AGTC, Alector, Arkuda, Arvinas, Asceneuron, AZTherapeutics, Bioage, Ionis, Lundbeck, Passage BIO, Regeneron, Samumed, Transposon, and UCB, and received research support from Biogen, Eisai, Eli Lilly, Genentech, Novartis, Roche and TauRx. Go to Neurology.org/N for full disclosures.

\section{Publication History}

Received by Neurology July 25, 2019. Accepted in final form February 8, 2021.

Appendix 1 Authors

\begin{tabular}{|c|c|c|}
\hline Name & Location & Contribution \\
\hline $\begin{array}{l}\text { Julio C. Rojas, } \\
\text { MD, PhD }\end{array}$ & $\begin{array}{l}\text { University of California, } \\
\text { San Francisco }\end{array}$ & $\begin{array}{l}\text { Analyzed data, } \\
\text { performed statistical } \\
\text { analysis, drafted } \\
\text { manuscript }\end{array}$ \\
\hline Ping Wang, MS & $\begin{array}{l}\text { University of California, } \\
\text { San Francisco }\end{array}$ & $\begin{array}{l}\text { Clinical data collection } \\
\text { and critical revision of the } \\
\text { manuscript }\end{array}$ \\
\hline $\begin{array}{l}\text { Adam M. } \\
\text { Staffaroni, PhD }\end{array}$ & $\begin{array}{l}\text { University of California, } \\
\text { San Francisco }\end{array}$ & $\begin{array}{l}\text { Clinical data collection } \\
\text { and critical revision of the } \\
\text { manuscript }\end{array}$ \\
\hline $\begin{array}{l}\text { Carolin Heller, } \\
\text { BSc }\end{array}$ & $\begin{array}{l}\text { UCL Institute of } \\
\text { Neurology, Queen } \\
\text { Square, London, UK }\end{array}$ & $\begin{array}{l}\text { Clinical data collection } \\
\text { and critical revision of the } \\
\text { manuscript }\end{array}$ \\
\hline $\begin{array}{l}\text { Yann Cobigo, } \\
\text { PhD }\end{array}$ & $\begin{array}{l}\text { University of California, } \\
\text { San Francisco }\end{array}$ & $\begin{array}{l}\text { Imaging data collection } \\
\text { and critical revision of the } \\
\text { manuscript }\end{array}$ \\
\hline Amy Wolf, BS & $\begin{array}{l}\text { University of California, } \\
\text { San Francisco }\end{array}$ & $\begin{array}{l}\text { Imaging data collection } \\
\text { and critical revision of the } \\
\text { manuscript }\end{array}$ \\
\hline $\begin{array}{l}\text { Sheng-Yang M. } \\
\text { Goh, BS }\end{array}$ & $\begin{array}{l}\text { University of California, } \\
\text { San Francisco }\end{array}$ & $\begin{array}{l}\text { Imaging data collection } \\
\text { and critical revision of the } \\
\text { manuscript }\end{array}$ \\
\hline $\begin{array}{l}\text { Peter A. } \\
\text { Ljubenkov, MD }\end{array}$ & $\begin{array}{l}\text { University of California, } \\
\text { San Francisco }\end{array}$ & $\begin{array}{l}\text { Clinical data collection } \\
\text { and critical revision of the } \\
\text { manuscript }\end{array}$ \\
\hline
\end{tabular}

Appendix 1 (continued)

\begin{tabular}{|c|c|c|}
\hline Name & Location & Contribution \\
\hline $\begin{array}{l}\text { Hilary W. } \\
\text { Heuer, PhD }\end{array}$ & $\begin{array}{l}\text { University of California, } \\
\text { San Francisco }\end{array}$ & $\begin{array}{l}\text { Clinical data collection } \\
\text { and critical revision of the } \\
\text { manuscript }\end{array}$ \\
\hline $\begin{array}{l}\text { Jamie C. Fong, } \\
\text { MS }\end{array}$ & $\begin{array}{l}\text { University of California, } \\
\text { San Francisco }\end{array}$ & $\begin{array}{l}\text { Clinical data } \\
\text { collection and critical } \\
\text { revision of the } \\
\text { manuscript }\end{array}$ \\
\hline $\begin{array}{l}\text { Joanne B. } \\
\text { Taylor, MS }\end{array}$ & $\begin{array}{l}\text { University of California, } \\
\text { San Francisco }\end{array}$ & $\begin{array}{l}\text { Clinical data collection } \\
\text { and critical revision of the } \\
\text { manuscript }\end{array}$ \\
\hline Eliseo Veras, BS & $\begin{array}{l}\text { Quanterix Corp, } \\
\text { Lexington, MA }\end{array}$ & $\begin{array}{l}\text { Fluid biomarker data } \\
\text { collection and critical } \\
\text { revision of the } \\
\text { manuscript }\end{array}$ \\
\hline Linan Song & $\begin{array}{l}\text { Quanterix Corp, } \\
\text { Lexington, MA }\end{array}$ & $\begin{array}{l}\text { Fluid biomarker data } \\
\text { collection and critical } \\
\text { revision of the } \\
\text { manuscript }\end{array}$ \\
\hline $\begin{array}{l}\text { Andreas } \\
\text { Jeromin, PhD }\end{array}$ & $\begin{array}{l}\text { Quanterix Corp, } \\
\text { Lexington, MA }\end{array}$ & $\begin{array}{l}\text { Fluid biomarker data } \\
\text { collection and critical } \\
\text { revision of the } \\
\text { manuscript }\end{array}$ \\
\hline $\begin{array}{l}\text { David Hanlon, } \\
\text { PhD }\end{array}$ & $\begin{array}{l}\text { Quanterix Corp, } \\
\text { Lexington, MA }\end{array}$ & $\begin{array}{l}\text { Fluid biomarker data } \\
\text { collection and critical } \\
\text { revision of the } \\
\text { manuscript }\end{array}$ \\
\hline Lili Yu & $\begin{array}{l}\text { Novartis Institutes for } \\
\text { Biomedical Research Inc, } \\
\text { Cambridge, MA }\end{array}$ & $\begin{array}{l}\text { Fluid biomarker data } \\
\text { collection and critical } \\
\text { revision of the } \\
\text { manuscript }\end{array}$ \\
\hline Arvind Khinikar & $\begin{array}{l}\text { Novartis Institutes for } \\
\text { Biomedical Research Inc, } \\
\text { Cambridge, MA }\end{array}$ & $\begin{array}{l}\text { Fluid biomarker data } \\
\text { collection and critical } \\
\text { revision of the } \\
\text { manuscript }\end{array}$ \\
\hline $\begin{array}{l}\text { Rajeev } \\
\text { Sivasankaran, } \\
\text { PhD }\end{array}$ & $\begin{array}{l}\text { Novartis Institutes for } \\
\text { Biomedical Research Inc, } \\
\text { Cambridge, MA }\end{array}$ & $\begin{array}{l}\text { Fluid biomarker data } \\
\text { collection and critical } \\
\text { revision of the } \\
\text { manuscript }\end{array}$ \\
\hline $\begin{array}{l}\text { Agnieszka } \\
\text { Kieloch }\end{array}$ & $\begin{array}{l}\text { Novartis Pharma AG, } \\
\text { Basel, Switzerland }\end{array}$ & $\begin{array}{l}\text { Fluid biomarker data } \\
\text { collection and critical } \\
\text { revision of the } \\
\text { manuscript }\end{array}$ \\
\hline $\begin{array}{l}\text { Marie-Anne } \\
\text { Valentin }\end{array}$ & $\begin{array}{l}\text { Novartis Pharma AG, } \\
\text { Basel, Switzerland }\end{array}$ & $\begin{array}{l}\text { Fluid biomarker data } \\
\text { collection and critical } \\
\text { revision of the } \\
\text { manuscript }\end{array}$ \\
\hline $\begin{array}{l}\text { Anna M. } \\
\text { Karydas }\end{array}$ & $\begin{array}{l}\text { University of California, } \\
\text { San Francisco }\end{array}$ & $\begin{array}{l}\text { Clinical data collection } \\
\text { and critical revision of the } \\
\text { manuscript }\end{array}$ \\
\hline $\begin{array}{l}\text { Laura L. Mitic, } \\
\text { PhD }\end{array}$ & $\begin{array}{l}\text { University of California, } \\
\text { San Francisco }\end{array}$ & $\begin{array}{l}\text { Clinical data } \\
\text { collection and critical } \\
\text { revision of the } \\
\text { manuscript }\end{array}$ \\
\hline $\begin{array}{l}\text { Rodney } \\
\text { Pearlman }\end{array}$ & $\begin{array}{l}\text { Bluefield Project to Cure } \\
\text { Frontotemporal } \\
\text { Dementia, San } \\
\text { Francisco, CA }\end{array}$ & $\begin{array}{l}\text { Clinical data collection } \\
\text { and critical revision of the } \\
\text { manuscript }\end{array}$ \\
\hline $\begin{array}{l}\text { John Kornak, } \\
\text { PhD }\end{array}$ & $\begin{array}{l}\text { University of California, } \\
\text { San Francisco }\end{array}$ & $\begin{array}{l}\text { Data analysis, statistical } \\
\text { analysis, and critical } \\
\text { revision of the } \\
\text { manuscript }\end{array}$ \\
\hline
\end{tabular}

Continued 
Appendix 1 (continued)

\begin{tabular}{|c|c|c|}
\hline Name & Location & Contribution \\
\hline $\begin{array}{l}\text { Joel H. Kramer, } \\
\text { PsyD }\end{array}$ & $\begin{array}{l}\text { University of California, } \\
\text { San Francisco }\end{array}$ & $\begin{array}{l}\text { Clinical data collection } \\
\text { and critical revision of the } \\
\text { manuscript }\end{array}$ \\
\hline $\begin{array}{l}\text { Bruce L. Miller, } \\
\text { MD }\end{array}$ & $\begin{array}{l}\text { University of California, } \\
\text { San Francisco }\end{array}$ & $\begin{array}{l}\text { Clinical data collection } \\
\text { and critical revision of the } \\
\text { manuscript }\end{array}$ \\
\hline $\begin{array}{l}\text { Kejal Kantarci, } \\
\text { MD }\end{array}$ & $\begin{array}{l}\text { Mayo Clinic, Rochester, } \\
\text { MN, }\end{array}$ & $\begin{array}{l}\text { Clinical data collection } \\
\text { and critical revision of the } \\
\text { manuscript }\end{array}$ \\
\hline $\begin{array}{l}\text { David S. } \\
\text { Knopman, MD }\end{array}$ & $\begin{array}{l}\text { Mayo Clinic, Rochester, } \\
\text { MN }\end{array}$ & $\begin{array}{l}\text { Clinical data collection } \\
\text { and critical revision of the } \\
\text { manuscript }\end{array}$ \\
\hline $\begin{array}{l}\text { Neill Graff- } \\
\text { Radford, MD }\end{array}$ & $\begin{array}{l}\text { Mayo Clinic, Jacksonville, } \\
\text { FL }\end{array}$ & $\begin{array}{l}\text { Clinical data collection } \\
\text { and critical revision of the } \\
\text { manuscript }\end{array}$ \\
\hline $\begin{array}{l}\text { Leonard } \\
\text { Petrucelli, PhD }\end{array}$ & $\begin{array}{l}\text { Mayo Clinic, Jacksonville, } \\
\text { FL }\end{array}$ & $\begin{array}{l}\text { Clinical data collection } \\
\text { and critical revision of the } \\
\text { manuscript }\end{array}$ \\
\hline $\begin{array}{l}\text { Rosa } \\
\text { Rademakers, } \\
\text { PhD }\end{array}$ & $\begin{array}{l}\text { Mayo Clinic, Jacksonville, } \\
\text { FL }\end{array}$ & $\begin{array}{l}\text { Clinical data collection } \\
\text { and critical revision of the } \\
\text { manuscript }\end{array}$ \\
\hline $\begin{array}{l}\text { David J. Irwin, } \\
\text { MD }\end{array}$ & $\begin{array}{l}\text { University of } \\
\text { Pennsylvania, } \\
\text { Philadelphia }\end{array}$ & $\begin{array}{l}\text { Clinical data collection } \\
\text { and critical revision of the } \\
\text { manuscript }\end{array}$ \\
\hline $\begin{array}{l}\text { Murray } \\
\text { Grossman, MD, } \\
\text { EdD }\end{array}$ & $\begin{array}{l}\text { University of } \\
\text { Pennsylvania, } \\
\text { Philadelphia }\end{array}$ & $\begin{array}{l}\text { Clinical data collection } \\
\text { and critical revision of the } \\
\text { manuscript }\end{array}$ \\
\hline $\begin{array}{l}\text { Eliana Marisa } \\
\text { Ramos, PhD }\end{array}$ & $\begin{array}{l}\text { University of California, } \\
\text { Los Angeles }\end{array}$ & $\begin{array}{l}\text { Clinical data collection } \\
\text { and critical revision of the } \\
\text { manuscript }\end{array}$ \\
\hline $\begin{array}{l}\text { Giovanni } \\
\text { Coppola, MD }\end{array}$ & $\begin{array}{l}\text { University of California, } \\
\text { Los Angeles }\end{array}$ & $\begin{array}{l}\text { Clinical data collection } \\
\text { and critical revision of the } \\
\text { manuscript }\end{array}$ \\
\hline $\begin{array}{l}\text { Mario F. } \\
\text { Mendez, MD, } \\
\text { PhD }\end{array}$ & $\begin{array}{l}\text { University of California, } \\
\text { Los Angeles }\end{array}$ & $\begin{array}{l}\text { Clinical data collection } \\
\text { and critical revision of the } \\
\text { manuscript }\end{array}$ \\
\hline $\begin{array}{l}\text { Yvette } \\
\text { Bordelon, MD, } \\
\text { PhD }\end{array}$ & $\begin{array}{l}\text { University of California, } \\
\text { Los Angeles }\end{array}$ & $\begin{array}{l}\text { Clinical data collection } \\
\text { and critical revision of the } \\
\text { manuscript }\end{array}$ \\
\hline $\begin{array}{l}\text { Bradford C. } \\
\text { Dickerson, MD }\end{array}$ & $\begin{array}{l}\text { Harvard University/ } \\
\text { Massachusetts General } \\
\text { Hospital, Boston, MA }\end{array}$ & $\begin{array}{l}\text { Clinical data collection } \\
\text { and critical revision of the } \\
\text { manuscript }\end{array}$ \\
\hline $\begin{array}{l}\text { Nupur Ghoshal, } \\
\text { MD }\end{array}$ & $\begin{array}{l}\text { Washington University, } \\
\text { St. Louis, MO }\end{array}$ & $\begin{array}{l}\text { Clinical data collection } \\
\text { and critical revision of the } \\
\text { manuscript }\end{array}$ \\
\hline $\begin{array}{l}\text { Edward D. } \\
\text { Huey, MD }\end{array}$ & $\begin{array}{l}\text { Columbia University, } \\
\text { New York, NY }\end{array}$ & $\begin{array}{l}\text { Clinical data collection } \\
\text { and critical revision of the } \\
\text { manuscript }\end{array}$ \\
\hline $\begin{array}{l}\text { lan } R . \\
\text { Mackenzie, MD }\end{array}$ & $\begin{array}{l}\text { University of British } \\
\text { Columbia, Vancouver, } \\
\text { Canada }\end{array}$ & $\begin{array}{l}\text { Clinical data collection } \\
\text { and critical revision of the } \\
\text { manuscript }\end{array}$ \\
\hline $\begin{array}{l}\text { Brian S. } \\
\text { Appleby, MD }\end{array}$ & $\begin{array}{l}\text { Case Western Reserve } \\
\text { University, Cleveland, } \mathrm{OH}\end{array}$ & $\begin{array}{l}\text { Clinical data collection } \\
\text { and critical revision of the } \\
\text { manuscript }\end{array}$ \\
\hline $\begin{array}{l}\text { Kimiko } \\
\text { Domoto-Reilly, } \\
\text { MD }\end{array}$ & $\begin{array}{l}\text { University of } \\
\text { Washington, Seattle }\end{array}$ & $\begin{array}{l}\text { Clinical data collection } \\
\text { and critical revision of the } \\
\text { manuscript }\end{array}$ \\
\hline
\end{tabular}

Appendix 1 (continued)

\begin{tabular}{|c|c|c|}
\hline Name & Location & Contribution \\
\hline $\begin{array}{l}\text { Ging-Yuek R. } \\
\text { Hsiung, MD }\end{array}$ & $\begin{array}{l}\text { University of British } \\
\text { Columbia, Vancouver, } \\
\text { Canada }\end{array}$ & $\begin{array}{l}\text { Clinical data collection } \\
\text { and critical revision of the } \\
\text { manuscript }\end{array}$ \\
\hline $\begin{array}{l}\text { Arthur W. Toga, } \\
\text { PhD }\end{array}$ & $\begin{array}{l}\text { Laboratory of } \\
\text { Neuroimaging, } \\
\text { University of Southern } \\
\text { California, Los Angeles }\end{array}$ & $\begin{array}{l}\text { Imaging data collection } \\
\text { and critical revision of the } \\
\text { manuscript }\end{array}$ \\
\hline $\begin{array}{l}\text { Sandra } \\
\text { Weintraub, PhD }\end{array}$ & $\begin{array}{l}\text { Northwestern University, } \\
\text { Chicago, IL }\end{array}$ & $\begin{array}{l}\text { Clinical data collection } \\
\text { and critical revision of the } \\
\text { manuscript }\end{array}$ \\
\hline $\begin{array}{l}\text { Daniel I. Kaufer, } \\
\text { MD }\end{array}$ & $\begin{array}{l}\text { University of North } \\
\text { Carolina, Chapel Hill }\end{array}$ & $\begin{array}{l}\text { Clinical data collection } \\
\text { and critical revision of the } \\
\text { manuscript }\end{array}$ \\
\hline $\begin{array}{l}\text { Diana Kerwin, } \\
\text { MD }\end{array}$ & $\begin{array}{l}\text { Texas Health } \\
\text { Presbyterian Hospital } \\
\text { Dallas, TX }\end{array}$ & $\begin{array}{l}\text { Clinical data collection } \\
\text { and critical revision of the } \\
\text { manuscript }\end{array}$ \\
\hline $\begin{array}{l}\text { Irene Litvan, } \\
\text { MD }\end{array}$ & $\begin{array}{l}\text { University of California, } \\
\text { San Diego }\end{array}$ & $\begin{array}{l}\text { Clinical data collection } \\
\text { and critical revision of the } \\
\text { manuscript }\end{array}$ \\
\hline $\begin{array}{l}\text { Chiadikaobi U. } \\
\text { Onyike, MD }\end{array}$ & $\begin{array}{l}\text { Johns Hopkins Hospital, } \\
\text { Baltimore, MD }\end{array}$ & $\begin{array}{l}\text { Clinical data collection } \\
\text { and critical revision of the } \\
\text { manuscript }\end{array}$ \\
\hline $\begin{array}{l}\text { Alexander } \\
\text { Pantelyat, MD }\end{array}$ & $\begin{array}{l}\text { Johns Hopkins Hospital, } \\
\text { Baltimore, MD }\end{array}$ & $\begin{array}{l}\text { Clinical data collection } \\
\text { and critical revision of the } \\
\text { manuscript }\end{array}$ \\
\hline $\begin{array}{l}\text { Erik D. } \\
\text { Roberson, MD, } \\
\text { PhD }\end{array}$ & $\begin{array}{l}\text { University of Alabama at } \\
\text { Birmingham }\end{array}$ & $\begin{array}{l}\text { Clinical data collection } \\
\text { and critical revision of the } \\
\text { manuscript }\end{array}$ \\
\hline $\begin{array}{l}\text { Maria C. } \\
\text { Tartaglia, MD }\end{array}$ & $\begin{array}{l}\text { University of Toronto, } \\
\text { Ontario, Canada }\end{array}$ & $\begin{array}{l}\text { Clinical data collection } \\
\text { and critical revision of the } \\
\text { manuscript }\end{array}$ \\
\hline $\begin{array}{l}\text { Tatiana Foroud, } \\
\text { PhD }\end{array}$ & $\begin{array}{l}\text { Indiana University School } \\
\text { of Medicine, Indianapolis }\end{array}$ & $\begin{array}{l}\text { Clinical data collection } \\
\text { and critical revision of the } \\
\text { manuscript }\end{array}$ \\
\hline $\begin{array}{l}\text { Weiping Chen, } \\
\text { MS }\end{array}$ & $\begin{array}{l}\text { Biogen Inc, Cambridge, } \\
\text { MA }\end{array}$ & $\begin{array}{l}\text { Fluid biomarker data } \\
\text { collection and critical } \\
\text { revision of the } \\
\text { manuscript }\end{array}$ \\
\hline $\begin{array}{l}\text { Julie } \\
\text { Czerkowicz, MS }\end{array}$ & $\begin{array}{l}\text { Biogen Inc, Cambridge, } \\
\text { MA }\end{array}$ & $\begin{array}{l}\text { Fluid biomarker data } \\
\text { collection and critical } \\
\text { revision of the } \\
\text { manuscript }\end{array}$ \\
\hline $\begin{array}{l}\text { Danielle L. } \\
\text { Graham, PhD }\end{array}$ & $\begin{array}{l}\text { Biogen Inc., Cambridge, } \\
\text { MA, USA }\end{array}$ & $\begin{array}{l}\text { Fluid biomarker data } \\
\text { collection and critical } \\
\text { revision of the } \\
\text { manuscript }\end{array}$ \\
\hline $\begin{array}{l}\text { John C. van } \\
\text { Swieten, PhD }\end{array}$ & $\begin{array}{l}\text { Erasmus Medical Centre, } \\
\text { Rotterdam, the } \\
\text { Netherlands }\end{array}$ & $\begin{array}{l}\text { Clinical data collection } \\
\text { and critical revision of the } \\
\text { manuscript }\end{array}$ \\
\hline $\begin{array}{l}\text { Barbara } \\
\text { Borroni, MD }\end{array}$ & $\begin{array}{l}\text { University of Brescia, } \\
\text { Italy }\end{array}$ & $\begin{array}{l}\text { Clinical data collection } \\
\text { and critical revision of the } \\
\text { manuscript }\end{array}$ \\
\hline $\begin{array}{l}\text { Raquel } \\
\text { Sanchez-Valle, } \\
\text { PhD }\end{array}$ & $\begin{array}{l}\text { University of Barcelona, } \\
\text { Spain }\end{array}$ & $\begin{array}{l}\text { Clinical data collection } \\
\text { and critical revision of the } \\
\text { manuscript }\end{array}$ \\
\hline $\begin{array}{l}\text { Fermin } \\
\text { Moreno, MD, } \\
\text { PhD }\end{array}$ & $\begin{array}{l}\text { Donostia University } \\
\text { Hospital, San Sebastian, } \\
\text { Gipuzkoa, Spain }\end{array}$ & $\begin{array}{l}\text { Clinical data collection } \\
\text { and critical revision of the } \\
\text { manuscript }\end{array}$ \\
\hline
\end{tabular}


Appendix 1 (continued)

\begin{tabular}{|c|c|c|}
\hline Name & Location & Contribution \\
\hline $\begin{array}{l}\text { Robert Laforce, } \\
\text { MD, PhD }\end{array}$ & $\begin{array}{l}\text { Université Laval, Québec, } \\
\text { Canada }\end{array}$ & $\begin{array}{l}\text { Clinical data collection } \\
\text { and critical revision of the } \\
\text { manuscript }\end{array}$ \\
\hline $\begin{array}{l}\text { Caroline Graff, } \\
\text { MD, PhD }\end{array}$ & $\begin{array}{l}\text { Karolinska Institutet, } \\
\text { Solna, Sweden; } \\
\text { Karolinska University } \\
\text { Hospital, Solna, Sweden }\end{array}$ & $\begin{array}{l}\text { Clinical data collection } \\
\text { and critical revision of the } \\
\text { manuscript }\end{array}$ \\
\hline $\begin{array}{l}\text { Matthis } \\
\text { Synofzik, MD }\end{array}$ & $\begin{array}{l}\text { University of Tübingen, } \\
\text { Germany; Center for } \\
\text { Neurodegenerative } \\
\text { Diseases (DZNE), } \\
\text { Tübingen, Germany }\end{array}$ & $\begin{array}{l}\text { Clinical data collection } \\
\text { and critical revision of the } \\
\text { manuscript }\end{array}$ \\
\hline $\begin{array}{l}\text { Daniela } \\
\text { Galimberti, PhD }\end{array}$ & $\begin{array}{l}\text { IRCCS Ospedale } \\
\text { Policlinico, Milan, Italy; } \\
\text { University of Milan, } \\
\text { Centro Dino Ferrari, Italy }\end{array}$ & $\begin{array}{l}\text { Clinical data collection } \\
\text { and critical revision of the } \\
\text { manuscript }\end{array}$ \\
\hline $\begin{array}{l}\text { James B. Rowe, } \\
\text { MD, PhD }\end{array}$ & $\begin{array}{l}\text { University of Cambridge, } \\
\text { UK }\end{array}$ & $\begin{array}{l}\text { Clinical data collection } \\
\text { and critical revision of the } \\
\text { manuscript }\end{array}$ \\
\hline $\begin{array}{l}\text { Mario Masellis, } \\
\text { MD, PhD }\end{array}$ & $\begin{array}{l}\text { University of Toronto, } \\
\text { Ontario, Canada }\end{array}$ & $\begin{array}{l}\text { Clinical data collection } \\
\text { and critical revision of the } \\
\text { manuscript }\end{array}$ \\
\hline $\begin{array}{l}\text { Elizabeth } \\
\text { Finger, MD }\end{array}$ & $\begin{array}{l}\text { University of Western } \\
\text { Ontario, London, Canada }\end{array}$ & $\begin{array}{l}\text { Clinical data collection } \\
\text { and critical revision of the } \\
\text { manuscript }\end{array}$ \\
\hline $\begin{array}{l}\text { Rik } \\
\text { Vandenberghe, } \\
\text { MD, PhD }\end{array}$ & $\begin{array}{l}\text { KU Leuven, Leuven, } \\
\text { Belgium; Neurology } \\
\text { Service, University } \\
\text { Hospitals Leuven, } \\
\text { Belgium }\end{array}$ & $\begin{array}{l}\text { Clinical data collection } \\
\text { and critical revision of the } \\
\text { manuscript }\end{array}$ \\
\hline $\begin{array}{l}\text { Alexandre de } \\
\text { Mendonça, MD, } \\
\text { PhD }\end{array}$ & $\begin{array}{l}\text { University of Lisbon, } \\
\text { Portugal }\end{array}$ & $\begin{array}{l}\text { Clinical data collection } \\
\text { and critical revision of the } \\
\text { manuscript }\end{array}$ \\
\hline $\begin{array}{l}\text { Fabrizio } \\
\text { Tagliavini, MD }\end{array}$ & $\begin{array}{l}\text { Fondazione IRCCS } \\
\text { Istituto Neurologico } \\
\text { Carlo Besta, Milano, Italy }\end{array}$ & $\begin{array}{l}\text { Clinical data collection } \\
\text { and critical revision of the } \\
\text { manuscript }\end{array}$ \\
\hline $\begin{array}{l}\text { Isabel Santana, } \\
\text { MD, PhD }\end{array}$ & $\begin{array}{l}\text { University of Coimbra, } \\
\text { Portugal }\end{array}$ & $\begin{array}{l}\text { Clinical data collection } \\
\text { and critical revision of the } \\
\text { manuscript }\end{array}$ \\
\hline $\begin{array}{l}\text { Simon } \\
\text { Ducharme, MD }\end{array}$ & $\begin{array}{l}\text { McGill University, } \\
\text { Montreal, Québec, } \\
\text { Canada }\end{array}$ & $\begin{array}{l}\text { Clinical data collection } \\
\text { and critical revision of the } \\
\text { manuscript }\end{array}$ \\
\hline $\begin{array}{l}\text { Chris R. Butler, } \\
\text { PhD, FRCP }\end{array}$ & University of Oxford, UK & $\begin{array}{l}\text { Clinical data collection } \\
\text { and critical revision of the } \\
\text { manuscript }\end{array}$ \\
\hline $\begin{array}{l}\text { Alexander } \\
\text { Gerhard, MD, } \\
\text { MRCP }\end{array}$ & $\begin{array}{l}\text { Wolfson Molecular } \\
\text { Imaging Centre, } \\
\text { University of Manchester, } \\
\text { UK; University of } \\
\text { Duisburg-Essen, } \\
\text { Duisburg, Germany }\end{array}$ & $\begin{array}{l}\text { Clinical data collection } \\
\text { and critical revision of the } \\
\text { manuscript }\end{array}$ \\
\hline $\begin{array}{l}\text { Johannes Levin, } \\
\text { MD }\end{array}$ & $\begin{array}{l}\text { Ludwig-Maximilians- } \\
\text { Universität München, } \\
\text { Munich, Germany }\end{array}$ & $\begin{array}{l}\text { Clinical data collection } \\
\text { and critical revision of the } \\
\text { manuscript }\end{array}$ \\
\hline $\begin{array}{l}\text { Adrian Danek, } \\
\text { MD }\end{array}$ & $\begin{array}{l}\text { Ludwig-Maximilians- } \\
\text { Universität München, } \\
\text { Munich, Germany }\end{array}$ & $\begin{array}{l}\text { Clinical data collection } \\
\text { and critical revision of the } \\
\text { manuscript }\end{array}$ \\
\hline $\begin{array}{l}\text { Markus Otto, } \\
\text { MD }\end{array}$ & $\begin{array}{l}\text { University of Ulm, } \\
\text { Germany }\end{array}$ & $\begin{array}{l}\text { Clinical data collection } \\
\text { and critical revision of the } \\
\text { manuscript }\end{array}$ \\
\hline
\end{tabular}

Appendix 1 (continued)

\begin{tabular}{|c|c|c|}
\hline Name & Location & Contribution \\
\hline $\begin{array}{l}\text { Sandro Sorbi, } \\
\text { MD }\end{array}$ & $\begin{array}{l}\text { Department of } \\
\text { Neuroscience, Psychology, } \\
\text { Drug Research and Child } \\
\text { Health, University of } \\
\text { Florence, and IRCCS } \\
\text { Fondazione Don Carlo } \\
\text { Gnocchi, Florence Italy }\end{array}$ & $\begin{array}{l}\text { Clinical data collection } \\
\text { and critical revision of the } \\
\text { manuscript }\end{array}$ \\
\hline
\end{tabular}

\begin{tabular}{lll}
\hline David M. Cash, & Dementia Research & Clinical data collection \\
PhD & Centre, UCL Institute of & $\begin{array}{l}\text { and critical revision of the } \\
\text { manuscript }\end{array}$ \\
& Neurology, Queen & Square, London, UK
\end{tabular}

\begin{tabular}{lll}
\hline $\begin{array}{l}\text { Rhian S. } \\
\text { Convery, MSc }\end{array}$ & $\begin{array}{l}\text { Dementia Research } \\
\text { Centre, UCL Institute of } \\
\text { Neurology, Queen } \\
\text { Square, London, UK }\end{array}$ & $\begin{array}{l}\text { Clinical data collection } \\
\text { and critical revision of the } \\
\text { manuscript }\end{array}$ \\
\hline $\begin{array}{l}\text { Martina } \\
\text { Bocchetta, PhD }\end{array}$ & $\begin{array}{l}\text { Dementia Research } \\
\text { Centre, UCL Institute of } \\
\text { Neurology, Queen } \\
\text { Square, London, UK }\end{array}$ & $\begin{array}{l}\text { Clinical data collection } \\
\text { and critical revision of the } \\
\text { manuscript }\end{array}$ \\
\hline $\begin{array}{l}\text { Martha Foiani, } \\
\text { MRes }\end{array}$ & $\begin{array}{l}\text { Dementia Research } \\
\text { Centre, UCL } \\
\text { Institute of Neurology, } \\
\text { Queen Square, } \\
\text { London, UK }\end{array}$ & $\begin{array}{l}\text { Clinical data collection } \\
\text { and critical revision of the } \\
\text { manuscript }\end{array}$ \\
& $\begin{array}{ll}\text { Dementia Research } \\
\text { Centre, UCL Institute } \\
\text { of Neurology, }\end{array}$ & $\begin{array}{l}\text { Clinical data collection } \\
\text { and critical revision of the } \\
\text { Queline V. }\end{array}$ \\
$\begin{array}{l}\text { Quen Square, } \\
\text { London, UK }\end{array}$ &
\end{tabular}

\begin{tabular}{lll}
\hline $\begin{array}{l}\text { Georgia } \\
\text { Peakman, MSc }\end{array}$ & $\begin{array}{l}\text { Dementia Research } \\
\text { Centre, UCL Institute of } \\
\text { Neurology, Queen } \\
\text { Square, London, UK }\end{array}$ & $\begin{array}{l}\text { Clinical data collection } \\
\text { and critical revision of the } \\
\text { manuscript }\end{array}$ \\
\hline $\begin{array}{l}\text { Lucy Russell, } \\
\text { PhD }\end{array}$ & $\begin{array}{l}\text { Dementia Research } \\
\text { Centre, UCL Institute of } \\
\text { Neurology, Queen } \\
\text { Square, London, UK }\end{array}$ & $\begin{array}{l}\text { Clinical data collection } \\
\text { and critical revision of the } \\
\text { manuscript }\end{array}$ \\
\hline $\begin{array}{l}\text { Imogen Swift, } \\
\text { MSc }\end{array}$ & $\begin{array}{l}\text { Dementia Research } \\
\text { Centre, UCL } \\
\text { Institute of } \\
\text { Neurology, Queen }\end{array}$ & $\begin{array}{l}\text { Clinical data collection } \\
\text { and critical revision of the } \\
\text { manuscript }\end{array}$ \\
& Square, London, UK &
\end{tabular}

Neurology, Queen

Square, London, UK

\begin{tabular}{lll}
\hline $\begin{array}{l}\text { Emily Todd, } \\
\text { MRes }\end{array}$ & $\begin{array}{l}\text { Dementia Research } \\
\text { Centre, UCL Institute of } \\
\text { Neurology, Queen } \\
\text { Square, London, UK }\end{array}$ & $\begin{array}{l}\text { Clinical data collection } \\
\text { and critical revision of the } \\
\text { manuscript }\end{array}$ \\
\hline $\begin{array}{l}\text { Jonathan D. } \\
\text { Rohrer, PhD }\end{array}$ & $\begin{array}{l}\text { Dementia Research } \\
\text { Centre, UCL } \\
\text { Institute of } \\
\text { Neurology, Queen } \\
\text { Square, London, UK }\end{array}$ & $\begin{array}{l}\text { Study concept, } \\
\text { supervision, data } \\
\text { collection and critical } \\
\text { revision of the } \\
\text { manuscript }\end{array}$ \\
\hline $\begin{array}{l}\text { Bradley F. } \\
\text { Boeve, MD }\end{array}$ & $\begin{array}{l}\text { Mayo Clinic, Rochester, } \\
\text { MN }\end{array}$ & $\begin{array}{l}\text { Study concept, } \\
\text { supervision, data } \\
\text { collection and critical } \\
\text { revision of the manuscript }\end{array}$ \\
& & \\
\hline $\begin{array}{l}\text { Howard J. } \\
\text { Rosen, MD }\end{array}$ & Sniversity of California, & $\begin{array}{l}\text { Study concept, } \\
\text { supervision, data } \\
\text { collection and critical } \\
\text { revision of the manuscript }\end{array}$ \\
& &
\end{tabular}

Adam L. Boxer, University of California, Study concept and design, MD, PhD San Francisco overall supervision, data collection and critical revision of the manuscript 
Appendix 2 Coinvestigators

Coinvestigators are listed at links.Iww.com/WNL/B350

\section{Appendix 3 Coinvestigators}

Coinvestigators are listed at links.Iww.com/WNL/B351

\section{References}

1. Blennow K, Zetterberg H. Biomarkers for Alzheimer's disease: current status and prospects for the future. J Intern Med 2018;284:643-663.

2. Liu S, Jin Y, Shi Z, et al. The effects of behavioral and psychological symptoms on caregiver burden in frontotemporal dementia, Lewy body dementia, and Alzheimer's disease: clinical experience in China. Aging Ment Health 2017;21:651-657.

3. Olszewska DA, Lonergan R, Fallon EM, Lynch T. Genetics of frontotemporal dementia. Curr Neurol Neurosci Rep 2016;16:107.

4. DeJesus-Hernandez M, Mackenzie IR, Boeve BF, et al. Expanded GGGGCC hexanucleotide repeat in noncoding region of C9ORF72 causes chromosome 9p-linked FTD and ALS. Neuron 2011;72:245-256.

5. Baker M, Mackenzie IR, Pickering-Brown SM, et al. Mutations in progranulin cause tau-negative frontotemporal dementia linked to chromosome 17. Nature 2006;442: 916-919.

6. Hutton M, Lendon CL, Rizzu P, et al. Association of missense and 5'-splice-site mutations in tau with the inherited dementia FTDP-17. Nature 1998;393:702-705.

7. Desmarais P, Rohrer JD, Nguyen QD, et al. Therapeutic trial design for frontotemporal dementia and related disorders. J Neurol Neurosurg Psychiatry 2019;90: 412-423.

8. Bacioglu M, Maia LF, Preische O, et al. Neurofilament light chain in blood and CSF as marker of disease progression in mouse models and in neurodegenerative diseases. Neuron 2016;91:56-66.

9. Sjogren M, Rosengren L, Minthon L, Davidsson P, Blennow K, Wallin A. Cytoskeleton proteins in CSF distinguish frontotemporal dementia from AD. Neurology 2000;54:1960-1964.

10. Rosengren LE, Karlsson JE, Karlsson JO, Persson LI, Wikkelso C. Patients with amyotrophic lateral sclerosis and other neurodegenerative diseases have increased levels of neurofilament protein in CSF. J Neurochem 1996;67:2013-2018.

11. de Jong D, Jansen RW, Pijnenburg YA, et al. CSF neurofilament proteins in the differential diagnosis of dementia. J Neurol Neurosurg Psychiatry 2007;78:936-938.

12. Pijnenburg YA, Janssen JC, Schoonenboom NS, et al. CSF neurofilaments in frontotemporal dementia compared with early onset Alzheimer's disease and controls. Dement Geriatr Cogn Disord 2007;23:225-230.

13. Ljubenkov PA, Staffaroni AM, Rojas JC, et al. Cerebrospinal fluid biomarkers predict frontotemporal dementia trajectory. Ann Clin Transl Neurol 2018;5:1250-1263.

14. Scherling CS, Hall T, Berisha F, et al. Cerebrospinal fluid neurofilament concentration reflects disease severity in frontotemporal degeneration. Ann Neurol 2014;75:116-126.

15. Gunnarsson M, Malmestrom C, Axelsson M, et al. Axonal damage in relapsing multiple sclerosis is markedly reduced by natalizumab. Ann Neurol 2011;69:83-89.

16. Winter B, Guenther R, Ludolph AC, Hermann A, Otto M, Wurster CD. Neurofilaments and tau in CSF in an infant with SMA type 1 treated with nusinersen. J Neurol Neurosurg Psychiatry 2019;90:1068-1069.

17. Rohrer JD, Woollacott IO, Dick KM, et al. Serum neurofilament light chain protein is a measure of disease intensity in frontotemporal dementia. Neurology 2016;87: 1329-1336.

18. Meeter LH, Dopper EG, Jiskoot LC, et al. Neurofilament light chain: a biomarker for genetic frontotemporal dementia. Ann Clin Transl Neurol 2016;3:623-636.

19. Boeve B, Bove J, Brannelly P, et al. The longitudinal evaluation of familial frontotemporal dementia subjects protocol: framework and methodology. Alzheimers Dement 2020;16:22-36.

20. Rohrer JD, Nicholas JM, Cash DM, et al. Presymptomatic cognitive and neuroanatomical changes in genetic frontotemporal dementia in the Genetic Frontotemporal Dementia Initiative (GENFI) study: a cross-sectional analysis. Lancet Neurol 2015; $14: 253-262$.
21. Miyagawa T, Brushaber D, Syrjanen J, et al. Utility of the global CDR $((\mathrm{R}))$ plus NACC FTLD rating and development of scoring rules: data from the ARTFL/ LEFFTDS Consortium. Alzheimers Dement 2020;16:106-117.

22. Heller C, Foiani MS, Moore K, et al. Plasma glial fibrillary acidic protein is raised in progranulin-associated frontotemporal dementia. J Neurol Neurosurg Psychiatry 2020;91:263-270.

23. Busner J, Targum SD. The Clinical Global Impressions Scale: applying a research tool in clinical practice. Psychiatry 2007;4:28-37.

24. Fahn S, Elton RL. The Unified Parkinson's Disease Rating Scale. In: Fahn S, Marden SD, Calne DB, Goldstein M, eds. Recent Developments in Parkinson's Disease. New Jersey; Macmillan Healthcare; Vol 2; 1987: 153-163.

25. Schwab R, England A. Projection Technique for Evaluating Surgery in Parkinson's Disease. London;ES Livingston; 1969.

26. Pfeffer RI, Kurosaki TT, Harrah CH Jr, Chance JM, Filos S. Measurement of functional activities in older adults in the community. J Gerontol 1982;37:323-329.

27. Cummings JL, Mega M, Gray K, Rosenberg-Thompson S, Carusi DA, Gornbein J. The Neuropsychiatric Inventory: comprehensive assessment of psychopathology in dementia. Neurology 1994;44:2308-2314.

28. Delis DC, Kramer JH, Kaplan E, Ober BA. California Verbal Learning Test-Adult Version-Manual.San Antonio; Psychological Corp; 2000.

29. Possin KL, Laluz VR, Alcantar OZ, Miller BL, Kramer JH. Distinct neuroanatomical substrates and cognitive mechanisms of figure copy performance in Alzheimer's disease and behavioral variant frontotemporal dementia. Neuropsychologia 2011;49:43-48.

30. Reitan RM. Validity of the Trail-Making Test as an indication of organic brain damage. Percept Mot Skills 1958;8:271-276.

31. Ramos EM, Dokuru DR, Van Berlo V, et al. Genetic screening of a large series of North American sporadic and familial frontotemporal dementia cases. Alzheimers Dement 2020;16:118-130.

32. Staffaroni AM, Cobigo Y, Goh SM, et al. Individualized atrophy scores predict dementia onset in familial frontotemporal lobar degeneration. Alzheimers Dement 2020;16:37-48.

33. Brambati SM, Renda NC, Rankin KP, et al. A tensor based morphometry study of longitudinal gray matter contraction in FTD. Neuroimage 2007;35:998-1003.

34. Benjamini Y, Hochberg Y. Controlling the false discovery rate: a practical and powerful approach to multiple testing. J R Statist Soc B 1995;57:298-300.

35. van der Ende EL, Meeter LH, Poos JM, et al. Serum neurofilament light chain in genetic frontotemporal dementia: a longitudinal, multicentre cohort study. Lancet Neurol 2019; 18:1103-1111.

36. Heuer HW, Wang P, Rascovsky K, et al. Comparison of sporadic and familial be havioral variant frontotemporal dementia (FTD) in a North American cohort. Alzheimers Dement 2020;16:60-70.

37. Knopman DS, Kramer JH, Boeve BF, et al. Development of methodology for conducting clinical trials in frontotemporal lobar degeneration. Brain 2008;131:2957-2968.

38. ALLFTLD Study. ARTFL-LEFFTDS Longitudinal Frontotemporal Lobar Degeneration: A Multisite Research Consortium [online]. Available at: allftd.org/. Accessed May 5, 2020

39. Food and Drug Administration. Early Alzheimer's Disease: Developing Drugs for Treatment. Guidance for Industry: Silver Spring, MD: US Department of Health and Human Services, Center for Drug Evaluation and Research; 2018.

40. Csaky K, Ferris F III, Chew EY, Nair P, Cheetham JK, Duncan JL. Report from the NEI/FDA endpoints workshop on age-related macular degeneration and inherited retinal diseases. Invest Ophthalmol Vis Sci 2017;58:3456-3463.

41. Thijssen EH, La Joie R, Wolf A, et al. Diagnostic value of plasma phosphorylated tau181 in Alzheimer's disease and frontotemporal lobar degeneration. Nat Med 2020; 26:387-397.

42. Preische O, Schultz SA, Apel A, et al. Serum neurofilament dynamics predicts neurodegeneration and clinical progression in presymptomatic Alzheimer's disease. Nat Med 2019;25:277-283.

43. Hoglinger GU, Melhem NM, Dickson DW, et al. Identification of common variants influencing risk of the tauopathy progressive supranuclear palsy. Nat Genet 2011;43:699-705.

44. Pottier C, Zhou X, Perkerson RB III, et al. Potential genetic modifiers of disease risk and age at onset in patients with frontotemporal lobar degeneration and GRN mutations: a genome-wide association study. Lancet Neurol 2018;17:548-558.

45. Yokoyama JS, Karch CM, Fan CC, et al. Shared genetic risk between corticobasa degeneration, progressive supranuclear palsy, and frontotemporal dementia. Acta Neuropathol 2017;133:825-837.

46. Lu CH, Macdonald-Wallis $\mathrm{C}$, Gray E, et al. Neurofilament light chain: a prognostic biomarker in amyotrophic lateral sclerosis. Neurology 2015;84:2247-2257.

47. Rojas JC, Karydas A, Bang J, et al. Plasma neurofilament light chain predicts progression in progressive supranuclear palsy. Ann Clin Transl Neurol 2016;3:216-225. 


\section{Neurology}

\section{Plasma Neurofilament Light for Prediction of Disease Progression in Familial Frontotemporal Lobar Degeneration}

Julio C. Rojas, Ping Wang, Adam M. Staffaroni, et al.

Neurology 2021;96;e2296-e2312 Published Online before print April 7, 2021

DOI 10.1212/WNL.0000000000011848

This information is current as of April 7, 2021

Neurology ${ }^{\circledR}$ is the official journal of the American Academy of Neurology. Published continuously since 1951, it is now a weekly with 48 issues per year. Copyright Copyright (C) 2021 The Author(s). Published by Wolters Kluwer Health, Inc. on behalf of the American Academy of Neurology.. All rights reserved. Print ISSN: 0028-3878. Online ISSN: 1526-632X.

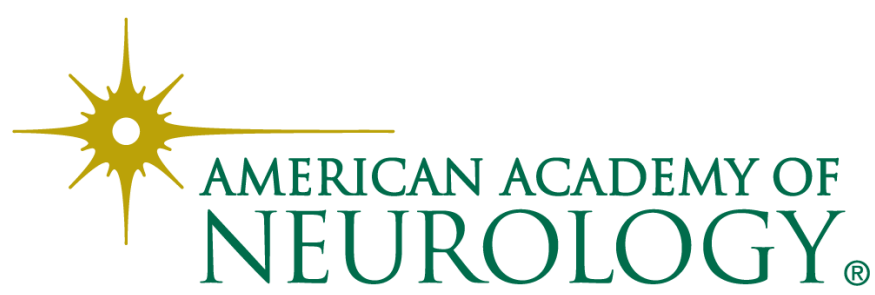




\section{Updated Information \& Services}

References

Citations

Subspecialty Collections

\section{Permissions \& Licensing}

Reprints including high resolution figures, can be found at: http://n.neurology.org/content/96/18/e2296.full

This article cites 42 articles, 8 of which you can access for free at: http://n.neurology.org/content/96/18/e2296.full\#ref-list-1

This article has been cited by 2 HighWire-hosted articles: http://n.neurology.org/content/96/18/e2296.full\#\#otherarticles

This article, along with others on similar topics, appears in the following collection(s):

\section{Class I}

http://n.neurology.org/cgi/collection/class_1 Clinical trials Observational study (Cohort, Case control) http://n.neurology.org/cgi/collection/clinical_trials_observational_stud y_cohort_case_control

\section{Frontotemporal dementia}

http://n.neurology.org/cgi/collection/frontotemporal_dementia MCI (mild cognitive impairment)

http://n.neurology.org/cgi/collection/mci_mild_cognitive_impairment Neuropsychological assessment

http://n.neurology.org/cgi/collection/neuropsychological_assessment Prognosis

http://n.neurology.org/cgi/collection/prognosis

Information about reproducing this article in parts (figures,tables) or in its entirety can be found online at:

http://www.neurology.org/about/about_the_journal\#permissions

Information about ordering reprints can be found online:

http://n.neurology.org/subscribers/advertise

Neurology ${ }^{\circledR}$ is the official journal of the American Academy of Neurology. Published continuously since 1951, it is now a weekly with 48 issues per year. Copyright Copyright ( 2021 The Author(s). Published by Wolters Kluwer Health, Inc. on behalf of the American Academy of Neurology.. All rights reserved. Print ISSN: 0028-3878. Online ISSN: 1526-632X.

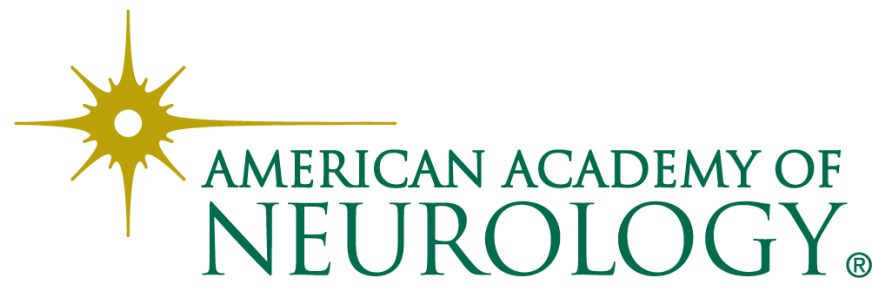

